\title{
Türkiye’de Sosyal Medya Konulu Doktora Tezlerinin İncelenmesi
}

\section{An Examination of the PhD Theses on Social Media in Turkey}

\author{
Dr. Öğr. Üyesi Özgür KIRAN (iD) 1 \\ $\ddot{O} \mathbf{z}$
}

Sosyal medya sayesinde iletişim alanında yakınlık ve uzaklık da anlamını büyük ölçüde yitirmiştir. Gündelik yaşamdaki her türlü ilişside sosyal medyanın rolü giderek artmaktadır. Bu çalışmada sosyal medya olgusunun bilimsel anlamda ne derece ve ne türden çalışmalarla ele alındığının ortaya konulması amaçlanmıştır. Yükseköğretim Kurulu (YÖK) Ulusal Tez Merkezi verilerine bağlı olarak yapılan literatür taramasının sonucunda, sosyal medya konusunda Türkiye'de yapılan doktora tezlerinin başlangıç tarihinin 2011 y1lı olduğu ve 2020 yılı Ocak ayı itibarıla bu konuda toplam 148 doktora tezi olduğu ancak bunlardan 135 'ine erişim izni verildiği görülmüştür. Türkiye'de sosyal medya konulu doktora tezlerinin hazırlandığı üniversiteler incelendiğinde toplam 45 üniversitede çalışıldığ \%89,7'sinin (38) devlet üniversitesi, \%10,3'ünün ise (7) vakıf üniversitesi olduğu tespit edilmiştir. Sosyal medya konulu doktora tezlerinde kullanılan araştırma yöntemleri incelendiğinde; \%50,4'ün de nicel araştırma yöntemlerinin kullanıldığı, \%33,3'ünde nitel yöntemlerin, \%16,3'ünde ise karma (hem nicel hem nitel) yöntemlerin kullanıldığı görülmüş̧ür. Kullanılan araştırma teknikleri incelendiğinde; ilk sırada $\% 42,2$ ile anket ve ölçeklerin bir arada kullanıldığ analizi tekniği gelmekte, üçüncü sırada ise $\% 5,9$ ile görüşme tekniği gelmektedir. Birey ve toplum hayatında giderek daha fazla yer edinmesine bağlı olarak bu konu ile ilgilenen bilim dallarının da çeşitlendiği ve buna bağlı olarak araştırma yöntem ve tekniklerinde de aynı yönde bir artışın olduğu belirtilebilir.

Anahtar Kelimeler: İletişim sosyolojisi, sosyal medya, yeni medya, doktora tezleri

Makale Türü: Araştırma

\begin{abstract}
By virtue of social media, the proximity and remoteness also lost their meanings in the area of communication to a large extent. In every type of relationship in daily life, the role played by the social media is gradually multiplied. In this study, it is aimed to reveal to what extent and with what kind of studies the social media phenomenon has been discussed scientifically. As per the literature review conducted on the basis of the databases of the National Thesis Center of the Council of Higher Education of Turkey (YÖK), it was discerned that the starting year of the doctoral dissertations which were prepared in Turkey on the topic of social media was 2011 and there were a total of 148 doctoral dissertations on this topic until January 2020, however, the permission to access was granted only to 135 out of all dissertations. In Turkey, upon the review of universities where doctoral dissertations were composed on the topic of social media, it was found that social media was studied in 45 universities and, of these universities, $89.7 \%$ (38) were public universities whilst $10.3 \%$ (7) were foundation universities. The review of research methods which were used in doctoral dissertations on the topic of social media indicated that quantitative research methods were used in $50.4 \%$ of the dissertations, qualitative research methods were used in 33.3\% of the dissertations and mixed-type research methods (both quantitative and qualitative) were used in $16.3 \%$ of the dissertations. As per the exploration of research techniques which were utilized, studies in which surveys and scales were used together came at the top with $42.2 \%$ of the dissertations. The content analysis comes second with $14.8 \%$ and is followed by the interview technique ranking third with 5.9\%. It can be further stated that scientific disciplines interested in this topic also get diversified as the social media gradually gains more ground in the life of individual and society, and hence, in the same direction, there is also an increase in the number of research methods and techniques.
\end{abstract}

\footnotetext{
${ }^{1}$ Samsun Üniversitesi, İktisadi, İdari ve Sosyal Bilimler Fakültesi, ozgur.kiran@ samsun.edu.tr

Atıf için (to cite): Kıran, Ö. (2021). Türkiye'de sosyal medya konulu doktora tezlerinin incelenmesi. Afyon Kocatepe Üniversitesi Sosyal Bilimler Dergisi, 23(3), 1066-1085.
} 
Keywords: Communication sociology, social media, new media, doctoral dissertations

Paper Type: Research

\section{Giriș}

İletişim olgusu insanlık tarihi kadar eski olduğu gibi birçok bilimin de ortak çalışma alanı ve konusu olmuştur. İnsanlar arasındaki iletişimin gelişen teknolojiye bağlı olarak niteliğinin değişmesi, bireyler arasındaki etkileşimin içeriğinde de farklılıklara yol açmıştır. Özellikle 20. yüzyıldan itibaren kitle iletişiminin küresel boyuta yayılması iletişim kavramına yüklenen anlamın değişmesine ve ortaya çıkan her yeni kitle iletişim aracıyla da iletişim kavramının yeniden ele alınmasına sebebiyet vermiştir. Bugün gelinen noktada kitle iletişim araçları Marshall McLuhan'1n (1962, s. 31) tabiriyle dünyayı küresel bir köye dönüştürmüş, birey ve toplumların yaşamında büyük değişikliklere yol açmış ve özel ilişkilerden resmi ilişkilere kadar her alanda açmaya da devam etmektedir. Kavramsal anlamda zaman ve mekân artık bağlayıc1, belirleyici özelliklerini yitirmiş ve her şey küresel çerçevede belirli bir 'an' da yaşanır hale gelmiştir. Kuşkusuz gelinen bu noktada en önemli medya aracı da internet ve dolayısıyla sosyal medya olmuştur. Sosyal medya sayesinde iletişim alanında yakınlık ve uzaklık da anlamını büyük ölçüde yitirmiştir. Gündelik yaşamdaki her türlü (formel-informel) ilişki ve etkileşimlerde sosyal medyanın rolü giderek artmaktadır.

Teknolojinin hızla gelişmesi, iletişim araçlarının dijitalleşmesi iletişim araç ve yöntemlerinin yeniden şekillenmesini ve yorumlanmasını da beraberinde getirmiştir (Poyraz, 2016, s. 62). Sosyal medya iletişiminin gelişimine neden olarak ise teknolojik gelişmelerle paralel giden bir bilgi açlığı ve iletişim hayranlığ gösterilebilir (Esen, 2019, s. 84). Popüler sosyal medya platformları düşünce ve kanaatlerin paylaşımında bireyle sınırlı kalmayıp, kitleleri harekete geçirebilecek bir propaganda aracı niteliğine bürünmüşlerdir (Alp, 2019, s. 42). Bu nedenle sosyal medya platformları, yeni medya konusunda araştırma yapanlara; yeni medya üzerine tartışabilmek, araştırma konu ve alanını etkileşim içerisinde kullanabilmek adına geniş imkânlar sağlamaktadır (Bayraktutan, 2014, s. 14). Ortaya çıkan bahsi geçen imkânlar ise; Türkiye'de iletişimle ilgili araştırmaları artırmıştır (Erdoğan, 2013, s. 210). Sosyal medya günümüzde bireyler için yalnızca bir eğlence ve bilgi edinme kaynağı değildir. Bu mecra üzerinden hemen her türlü ticari, ekonomik faaliyet kendine bir yer bulmaya çalışmakta ve bu sayede birey ve toplum üzerinde psiko-sosyal etkilerinin yanı sıra siyasal, kültürel ve özellikle öne çıkan ekonomik yönleri etki alanını genişletmektedir.

Geleneksel medyayı ve yeni medyayı birlikte uygulayan işletmeler, mevcut paydaşlarıyla olan ilişskilerini güçlendirir ve artırırken daha önce ulaşılmaz veya görünmez olan paydaşlarına da ulaşma ve onlarla karşılıklı etkileşim kurma imkânı bulmaktadırlar (Hearn, Foth and Gray (2009) dan aktaran; Binbaşıoğlu, Deste ve Ünal, 2015, s. 89).

Kitle kültürü, medyanın etkileri, kamuoyu üzerine incelemeler, internet ve bilgisayar üzerine çalışmalar bulundukları döneme ait teknik yeniliklere ilişkin çeşitli kaynaklar geliştirirler. Bu bağlamda yeni iletişim çalışmalarında, iletişim süreci yalnızca ileti alımlanması açısından değil, sürecin tamamının değerlendirilmesiyle bakış açısı değişmek zorunda kalmıştır. Bütün bu gereksinimler iletişim bilimleri tarafından araştırılan konuların tek yönlü bir bakış açısıyla kavranamayacak konular olduğunu göstermektedir (Ateş, 2016, s. 219). Bir araştırma ile bilimin genel amacı olan "görüngüdeki düzeni, tekrarlanan kalıpları, oluşum ve değişimin nedenlerini" bulmak amaçlanır. Benzer şekilde, iletişim araştırmalarının amacı genelde endüstriyel yapıda verimlilik, iletişim, pazarlama, etki ve meşrulaştırma sorunlarını çözme şeklinde inşa edilmektedir. Türkiye'de işletme, halkla ilişsiler, televizyon ve sinema, reklam, gibi farklı alanlarda anket tekniğiyle yapılmış araştırmalarda ise genellikle bu amaç güdülmez. Bu bağlamda, örnek olarak "aktif izleyici" (Song vd., 2004, s. 385) tezi vardır ve izleyici tercihlerini ve özelliklerini öğrenmeye dönük araştırma ve ölçme yöntemleri geliştirilmiştir. 
Pozitivizmin biçimlendirilmesine dayanan bu tür araştırma yöneliminin yanı sıra, "dışarıda bilinebilir bir gerçek yoktur, gerçek görecelidir, çoğuldur, sürekli değişim vardır ve tekrarlanan kalıplar yoktur, postmodernlik modernizmin bir devamı değildir" gibi açıklamalar popülerlik kazanmıştır (Erdoğan, 2013, s. 189).

Literatürde Türkiye'de yapılmış benzer çalışmalara örnek olarak; Davulcu ve Tanyeri'nin (2018) "İletişim Araştırmalarında 2006-2016 Yılları Arasında Yapılan Doktora Tezlerine İlişkin Bir Durum Değerlendirmesi” adlı çalışma kapsam genişliği konusunda önemli bir fikir kaynağıdır. Karakaya (2019) "Sosyolojik Araştırma, Yöntem Ve Tekniklerinin Sosyal Medya Üzerinden Kullanımı" adlı çalışmasında bu yöntem ve tekniklerin sosyal medya kullanımının avantaj ve dezavantajlarından bahsetmiştir. Devrani ve Kesici (2020) "Yeni Medya Araştırmalarında Yöntemler Ve Araçlar Ne Kadar Yeni? Türkiye'deki Lisansüstü Tezlere Dair Bir Analiz Çalışması" adlı araştırmalarında Türkiye'deki iletişim çalışmalarında yeni yöntem arayışları ve uygulama örneklerine değinmişler ve 2013-2018 yılları arasında yeni medya konulu lisansüstü tezlerinin araştırma yöntemleri, doküman inceleme ve meta analiz yöntemiyle değerlendirilmiştir. Kavut (2019) "İletişim Araştırmalarında Kullanılan Yöntem ve Teknikler Üzerine Bir Değerlendirme" adlı araştırmasında iletişim alanında kullanılan yöntem ve teknikleri literatür taraması ile incelemiş ve 2013-2018 yılları arasındaki anabilim dalı iletişim olan izinli doktora tezlerini yıl, sayfa sayısı, üniversiteler, anabilim dalları, yöntem ve teknikleri bakımından analiz etmiştir. Ateş (2016) "Bir Bilim Dalı Olarak İletişim Bilimleri Alanının Türkiye'deki Konusal Kapsam Analizi" adlı araştırmasında Türkiye'de bir bilim dalı olarak İletişim Bilimleri alanını ve iletişim bilimleri kapsamında yer alan konu başlıklarını incelemiştir. Ateş, iletişim bilimleri alanında tamamlanan ilk doktora tezinin 1998 yılında olduğunu, iletişim bilimleri alanında en fazla doktora tezinin Marmara Üniversitesi'nde yapıldığını ve iletişim bilimleri kapsamında doktora düzeyinde en çok araştırılan konunun sinema olduğunu ortaya koymuştur. Özüdoğru'nun (2014), "Nitel Araştırmanın İletişim Araştırmalarında Rol ve Önemi Üzerine Bir Deneme" adlı çalışmasında, iletişim çalışmalarında nitel araştırmanın rol ve sorumlulukları çeşitli nitel yöntemlere ait örneklerle tartışılmıştır. Çalışmadaki örnekler iletişim etnografisi, eleştirel söylem çözümlemesi ve göstergebilim yöntemlerinden oluşmaktadır.

Günümüz dünyasında sosyal medyanın birey ve toplum hayatında merkezi konum edinmesiyle birlikte bu konuda küresel çapta farklı bilim alanlarında sistematik birçok çalışma yapılmış ve yapılmaya da devam etmektedir. Ancak bu çalışma sadece Türkiye'deki doktora tez çalışmaları ile sınırlı tutulmuştur. Literatür taramasına dayalı bu çalışmada Türkiye'de sosyal medya konulu doktora düzeyindeki çalışmaların özellikle anabilim dalları, konu, yıl ve yöntemler ile çalışma alanları açısından sınıflandırılmasıyla bu konuda çalışma yapmak isteyenlere belli bir fikir vermesi yönünde literatüre katkı sağlaması hedeflenmektedir.

\section{Amaç}

$\mathrm{Bu}$ çalışmada iletişim alanında geleneksel ve yeni medya şeklinde yapılan ayrıma bağlı olarak günümüzde birey ve toplum hayatında oldukça geniş yer bulan sosyal medya olgusunun bilimsel anlamda ne derece ve ne türden çalışmalarla ele alındığının ortaya konulması amaçlanmıştır. Sosyal medya olgusu sosyal bilimlerin sadece bir alanıyla ya da genel olarak sosyal bilimlerin inceleme alanıyla sınırlandırılamayacak kadar geniş bir uygulama alanına sahiptir. Bu nedenle iletişimi birçok yönüyle farklı boyutlara taşıyan sosyal medyaya akademik çalışmalarda nasıl yer verildiğinin ortaya konulması bu çalışmayı benzer çalışmalardan ayırmaktadır. Çalışmanın sosyal medya konusunda tez yazmayı, araştırma yapmayı düşünenlere özellikle konu ve yöntem belirlemede belli bir fikir verebileceği düşünülmektedir. Çalışmada Türkiye'de sosyal medya konusunda yapılmış tezler doktora düzeyindekilerle sınırlı tutulmuştur. 


\section{Yöntem}

Sosyal medya konusunda hazırlanmış doktora tezlerinin tarama modelinde incelendiği bu çalışmada literatür taraması tercih edilmiştir. Alan yazın derlemesi olarak da ifade edilen literatür taraması herhangi bir özet değil, belli bir konuda önceden yapılmış araştırmaların incelenmesidir. Literatür taramasının (alan yazın derlemelerinin) amaçları ise (a) araştırma problemini sınırlandırmak, (b) sorgulanacak yeni noktalar bulmak, (c) faydasız yaklaşımlardan kaçınmak, (d) yöntemsel içgörü kazanmak ve (e) öneriler olarak sıralanabilir (Kızıltepe, 2017, s. 36). Literatür taramalarının kendi içinde; bağlam değerlendirmesi, tarihsel değerlendirme, bütünleştirici değerlendirme, metodolojik değerlendirme, kendi çalışmalarını değerlendirme ve kuramsal değerlendirme (Neuman, 2016, s. 166) olmak üzere altı türü bulunmakla birlikte bu çalışma bütünleştirici değerlendirme türüne dayanarak hazırlanmıştır. Literatür taramalarındaki bütünleştirici değerlendirme; belli bir konudaki bilgi durumunun sunulduğu ve özetlendiği bir değerlendirme türüdür ve genellikle bir bağlam değerlendirmesiyle de birleştirilebilir (Neuman, 2016, s. 166). Araştırma yöntemi olarak alanyazın tarama; meta analiz, meta sentez ve betimsel olarak üçe ayrılabilir. Özellikle bu çalışma ile ilgili olmak üzere betimsel tarama modelinde birbirinden bağımsız olarak yapılan nicel ve nitel çalışmalar incelenip düzenlenmiştir. Ancak bu tür çalışmalarda incelenen araştırma sayısının fazla olması derinlemesine yorum ve sentezi sinırlandırmaktadır (Çalık ve Sözbilir, 2014, s. 34). Araştırılacak konunun özgünlük derecesinin belirlenmesine yardımcı olması, konuyla ilgili ne tür araştırmalar yapıldığının ortaya konularak, yapılacak araştırmanın boyutları hakkında zengin bir içerik sağlaması ve konuyla ilgili terminolojiyi öğrenmeye ve geliştirmeye olanak sağlayarak gelecekte yapılacak araştırmalarla ilgili öngörüleri artırması, literatür taramasına dayalı araştırmaların sağladığı yararlardan bazılarıdır (Çalık, 2019, s. 20).

Yükseköğretim Kurulu Ulusal Tez Merkezi verilerine (YÖK Tez Merkezi, 2020) bağl1 olarak yapılan literatür taramasının sonucunda, sosyal medya konusunda Türkiye'de tamamlanmış ilk doktora tezlerinin başlangıç yılının 2011 yılı olduğu görülmüsstür. 2020 yılı Ocak ayı itibarıyla bu konuda toplam 148 doktora tezi olduğu ancak bunlardan 135'ine erişim izni verildiği tespit edilmiştir. Doktora tezlerinin incelenebilir sayıda olduğu varsayılarak 2011 yılından itibaren erişim izni verilmiş olanların tümü (135 tez) araştırma kapsamına dâhil edilmiş (Ek Tablo 1), ayrıca yıl sınırlandırılmasına gerek duyulmamıştır. Araştırmaların arama stratejileri içerisinde dâhil etme kriterleri olarak tez başlıkları incelenmiş, "sosyal medya" ve "yeni medya" kelimelerine yer verilmiştir. Yine konuyla ilgili olarak tamamlanmış ve erişim izni verilmiş olan doktora tezlerine Yükseköğretim Kurulu Tez Merkezi resmi internet sitesi (YÖK Tez Merkezi, 2020) üzerinden birincil kaynaktan ulaşılmıştır. Konuyla ilgili erişim izni verilmeyen tezler ile doktora tezleri dışındaki kaynaklar ve başlık dışındaki taramalar hariç tutulmuştur.

Bu bağlamda öncelikle tarama aracı olarak Yükseköğretim Kurulu Tez Merkezi resmi web sayfasında tarama terimi bölümüne "sosyal medya" kelimeleri yazılmış, daha sonra tez türü bölümünden "doktora" seçeneği ve izin durumu bölümünde de "izinli" seçeneği işaretlenerek, başlıklardan hareketle sosyal medya konulu doktora tezlerinin sayısı tespit edilmiştir. Bu tezler içerisinden erişim izni verilmiş olanlar indirilerek üniversite, anabilim dalı, yıl, konu ve kullanılan yöntem olarak tasnif edilecek şekilde bir form hazırlanarak kategorilendirilmiş ve frekans tablolarında sunulmuştur.

\section{Bulgular}

Üniversitelerin birçoğunda aynı alandaki anabilim dallarının kurumsal isimleri birebir aynı değildir. Bu anlamda çalışmada, aynı alanda olup da farklı isimlendirilen anabilim dalları, çoğunluğun sahip olduğu anabilim dalının ismi altında toplanmış olup bu anabilim dalları şunlardır: "Yabancı Diller Anabilim Dalı" adı altında (\%2,2); Batı Dil ve Edebiyatı Anabilim Dalı ile Çeviribilim Anabilim Dalı yer almakta; "Halkla İlişkiler ve Tanıtım Anabilim Dalı" adı altında (\%19,3); Halkla İlişkiler Anabilim Dalı ile Halkla İlişkiler ve Reklamcılık Anabilim Dalı 
yer almakta; "İletişim Bilimleri Anabilim Dalı" adı altında $(\% 7,4)$; İletişim Tasarım ve Yönetimi Anabilim Dalı, Medya ve İletişim Çalışmaları Anabilim Dalı ve Temel İletişim Bilimleri Anabilim Dalı yer almakta; "İşletme Anabilim Dalı" adı altında (\%28,8); İşletme Yönetimi Anabilim Dalı ile Sağlık Kurumları İşletmeciliği Anabilim Dalı yer almakta; "Radyo Televizyon Sinema Anabilim Dalı" adı altında, (\%5,9); Radyo Televizyon Anabilim Dalı ile Sinema Televizyon Anabilim Dalı yer almakta; "Siyaset Bilimi ve Kamu Yönetimi Anabilim Dalı" adı altında $(\% 5,2)$; Kamu Yönetimi Anabilim Dalı ile Uluslararası İlişkiler ve Siyaset Anabilim Dalı yer almakta; "Turizm İşletmeciliği Anabilim Dalı" adı altında $(\% 4,4)$; Turizm İşletmeciliği ve Otelcilik Anabilim Dalı yer almaktadır.

$\mathrm{Bu}$ bölümde sosyal medya konulu doktora tezlerinin çalışıldıkları üniversiteler, anabilim dalları, yıl, konu ve yöntemleri tablolar halinde incelenmiştir.

Tablo 1. Sosyal medya konulu doktora tezlerinin hazırlandığg üniversiteler

\begin{tabular}{|c|c|c|c|c|c|}
\hline Üniversiteler & $\mathrm{f}$ & $\%$ & Üniversiteler & $\mathrm{f}$ & $\%$ \\
\hline Adnan Menderes Ü. & 2 & 1,5 & İstanbul Bilgi Ü. & 1 &, 7 \\
\hline Afyon Kocatepe Ü. & 3 & 2,2 & İstanbul Ticaret Ü. & 2 & 1,5 \\
\hline Akdeniz Ü. & 4 & 3,0 & Karabük Ü. & 1 & ,7 \\
\hline Anadolu Ü. & 6 & 4,4 & Karadeniz Teknik Ü. & 1 &, 7 \\
\hline Ankara Ü. & 1 & ,7 & Kocaeli Ü. & 1 &, 7 \\
\hline Atatürk Ü. & 5 & 3,7 & Koç Ü. & 1 & ,7 \\
\hline Beykent Ü. & 6 & 4,4 & Maltepe Ü. & 1 & ,7 \\
\hline Boğaziçi Ü. & 1 &, 7 & Marmara Ü. & 17 & 12,6 \\
\hline Celal Bayar Ü. & 1 & ,7 & Mustafa Kemal Ü. & 1 & ,7 \\
\hline Çanakkale Onsekiz Mart & 1 & ,7 & Niğde Ömer Halis Demir & 1 & ,7 \\
\hline Çukurova Ü. & 1 & ,7 & ODTÜ & 1 & ,7 \\
\hline Dicle Ü. & 1 &, 7 & Okan Ü. & 2 & 1,5 \\
\hline Dumlupınar Ü. & 1 & ,7 & Pamukkale Ü. & 2 & 1,5 \\
\hline Ege Ü. & 2 & 1,5 & Polis Akademisi & 1 & ,7 \\
\hline Erciyes Ü. & 4 & 3,0 & Sakarya Ü. & 4 & 3,0 \\
\hline Gazi Ü. & 8 & 5,9 & Selçuk Ü. & 15 & 11,1 \\
\hline Gümüşhane Ü. & 1 &, 7 & Süleyman Demirel Ü. & 3 & 2,2 \\
\hline Hacettepe Ü. & 3 & 2,2 & Sütçü İmam Ü. & 3 & 2,2 \\
\hline Haliç Ü. & 1 & ,7 & Trakya Ü. & 1 & ,7 \\
\hline Hasan Kalyoncu Ü. & 1 &, 7 & Uludağ Ü. & 2 & 1,5 \\
\hline İnönü Ü. & 2 & 1,5 & Yaşar Ü. & 1 &, 7 \\
\hline İstanbul Ü. & 14 & 10,4 & Yıldız Teknik Ü. & 3 & 2,2 \\
\hline İstanbul Aydın Ü. & 1 &, 7 & & & \\
\hline
\end{tabular}

Tablo 1 de, Türkiye'de sosyal medya konulu doktora tezlerinin hazırlandığ1 üniversitelerin dağılımı yer almaktadır. Buna göre toplam 45 üniversitede sosyal medya konusunda çalış1ldığ1, bu üniversitelerin \%89,7'sinin (38) devlet üniversitesi, \%10,3'ünün ise (7) vakıf üniversitesi olduğu tespit edilmiştir. Genel olarak bakıldığında; ilk sırada \%12,6 oranıla (17 doktora tezi) Marmara Üniversitesi yer almaktadır. İkinci sirada \%11,1 ile (15 doktora tezi) Selçuk Üniversitesi, üçüncü sırada ise \%10,4 oranıyla (14 doktora tezi) İstanbul Üniversitesi gelmektedir. Bu Üniversiteleri \%5,9 ile (8 doktora tezi) Gazi Üniversitesi, 6'şar tez ile $(\% 4,4)$ Anadolu Üniversitesi ve Beykent Üniversitesi takip etmektedir.

Belirtilen üniversiteler içinde yedi tanesi (Beykent, Haliç, İstanbul Bilgi, İstanbul Ticaret, Koç, Okan ve Yaşar Üniversiteleri) vakıf üniversitesidir. Vakıf üniversitelerinde toplam 14 adet sosyal medya konulu doktora çalışması yapılırken bu sayının devlet üniversitelerine oranı \%10,3 dür. Vakıf üniversiteleri içerisinde ise sosyal medya konulu doktora tezi en fazla (6 adet, \%4,4) Beykent Üniversitesi’ne aittir. 
Tablo 2. Enstitülere göre doktora tezlerinin dağılımı

\begin{tabular}{lcc}
\hline \multicolumn{1}{c}{ Enstitüler } & $\mathrm{f}$ & $\%$ \\
\hline Eğitim Bilimleri Enstitüsü & 8 & 5,9 \\
\hline Fen Bilimleri Enstitüsü & 3 & 2,2 \\
\hline Güvenlik Bilimleri Enstitüsü & 1 &, 7 \\
\hline Lisansüstü Eğitim Enstitüsü & 1 &, 7 \\
\hline Sosyal Bilimler Enstitüsü & 122 & 90,4 \\
\hline Toplam & 135 & 100,0 \\
\hline
\end{tabular}

Tablo 2 de, Türkiye'de sosyal medya konulu doktora tezlerinin enstitülere göre dağılımı yapılmıştır. Buna göre ilgili tezlerin \%90,4'ünün Sosyal Bilimler Enstitüleri kapsamında çalışıldığı tespit edilmiştir. Son yıllarda Üniversitelerde Enstitülerin, Lisansüstü Eğitim Enstitüsü adı altında açılmasıyla tabloda görülen Lisansüstü Eğitim Enstitüsündeki konunun da İşletme anabilim dalında olması bu oranı \%91,1'e yükseltmektedir. Bunu \%5,9 ile Eğitim Bilimleri Enstitüleri takip etmektedir. Sosyal medyanın Fen Bilimleri Enstitüsü kapsamında az da olsa $(\% 2,2)$ çalış1lan bir konu olduğu görülmektedir.

Tablo 3. Anabilim dallarına göre doktora tezlerinin dağılımı

\begin{tabular}{lcc|lcc}
\hline Anabilim dalları & $\mathrm{f}$ & $\%$ & Anabilim dalları & $\mathrm{f}$ & $\%$ \\
\hline Beden Eğitimi ve Spor Öğrt. & 1 &, 7 & Işletme & 39 & 28,8 \\
\hline Bilgisayar Mühendisliği & 2 & 1,5 & Psikoloji & 1 &, 7 \\
\hline $\begin{array}{l}\text { Bilgisayar ve Öğretim } \\
\text { Teknolojileri }\end{array}$ & 3 & 2,2 & Radyo Televizyon Sinema & 8 & 5,9 \\
\hline $\begin{array}{l}\text { Çalışma Ekonomisi ve Endüstri } \\
\text { İlişkileri }\end{array}$ & 1 &, 7 & Reklamcılık & 1 &, 7 \\
\hline Eğitim Bilimleri & 2 & 1,5 & Sanat ve Tasarım & 2 & 1,5 \\
\hline Ekonometri & 1 &, 7 & Siyaset Bilimi ve Kamu & 7 & 5,2 \\
\hline Felsefe ve Din Bilimleri & 3 & 2,2 & Sönetimi & 5 & 3,7 \\
\hline Gazetecilik & 10 & 7,4 & Turizm İşletmeciliği & 6 & 4,4 \\
\hline Halkla İlişkiler ve Tanıtım & 26 & 19,3 & Uluslararası Güvenlik & 1 &, 7 \\
\hline İletişim Bilimleri & 10 & 7,4 & Yabancı Diller & 3 & 2,2 \\
\hline İlköğretim & 3 & 1,5 & Yönetim Bilgi & 1 &, 7 \\
\hline
\end{tabular}

Tablo 3 de, Türkiye'de sosyal medya konusunda hazırlanan doktora tezlerinin anabilim dallarına göre dağılımı gösterilmiştir. Buna göre \%28,1'inin İşletme Anabilim Dalı'nda, \%19'3'ünün Halkla İlişkiler ve Tanıtım Anabilim Dalı'nda, \%7,4'ünün İletişim Bilimleri ve yine \%7,4'ünün Gazetecilik Anabilim Dalı'nda hazırlandığı tespit edilmiştir. Ancak burada Gazetecilik, Halkla İlişkiler ve Tanıtım, Radyo Televizyon ve Sinema, Reklamcılık gibi anabilim dallarının tümü İletişim Bilimleri kapsamında değerlendirilebilir. Bu anlamda hepsini İletişim Bilimleri Anabilim Dalı altında düşündüğümüzde oran \%41,1 olmaktadır ki sosyal medya konulu doktora tezlerinin büyük çoğunluğunun $(\% 68,8)$ İletişim ve İşletme şeklinde iki alanda toplandığı görülmektedir.

Tablo 4. Y1llara göre doktora tezlerinin dağ 11 ımı

\begin{tabular}{|c|c|c|}
\hline Yillar & $\mathrm{f}$ & $\%$ \\
\hline 2011 & 3 & 2,2 \\
\hline 2012 & 6 & 4,4 \\
\hline 2013 & 8 & 5,9 \\
\hline 2014 & 12 & 8,9 \\
\hline 2015 & 18 & 13,3 \\
\hline 2016 & 16 & 11,9 \\
\hline 2017 & 12 & 8,9 \\
\hline 2018 & 23 & 17,0 \\
\hline 2019 & 37 & 27,4 \\
\hline Toplam & 135 & 100,0 \\
\hline
\end{tabular}


Tablo 4, yıllara göre Türkiye'de sosyal medya konulu doktora tezlerinin dağ 1 lımını göstermektedir. Buna göre 37 doktora tezi $(\% 27,4)$ ile en fazla çalışmanın 2019 yılında yapıldığı, ikinci sırada 23 tez ile (\%17) 2018 yılı, üçüncü sırada ise 18 tez ile $(\% 13,3) 2015$ yılının geldiği görülmektedir. Sosyal medya konulu doktora tez çalışmalarında (2016 ve 2017 yılları istisna olmak üzere) giderek artı̧̧ olduğu görülmektedir.

Tablo 5. Araştırma yöntemlerine göre doktora tezlerinin dağılımı

\begin{tabular}{lccc}
\hline & Yöntemler & f & $\%$ \\
\hline Karma & 22 & 16,3 \\
\hline Nicel & 68 & 50,4 \\
\hline Nitel & 45 & 33,3 \\
\hline Toplam & 135 & 100,0 \\
\hline
\end{tabular}

Tablo 5'de, sosyal medya konulu doktora tezlerinde kullanılan araştırma yöntemleri sınıflandırılmış olup, \%50,4'ün de nicel araştırma yöntemlerinin kullanıldığ 1 , \%33,3'ünde nitel yöntemlerin, \%16,3'ünde ise karma (hem nicel hem nitel) yöntemlerin kullanıldığı 1 görülmüştür. Buna göre incelenen tezlerin yarısı nicel yöntemlere dayalı olarak hazırlanmıştır.

Tablo 6. Doktora tezlerinde kullanılan veri toplama araçları ve veri analiz yöntemlerinin dağılımı

\begin{tabular}{|c|c|c|c|c|c|}
\hline $\begin{array}{c}\text { Veri Toplama Araçları ve Veri Analiz } \\
\text { Yöntemleri } \\
\end{array}$ & $\mathrm{f}$ & $\%$ & $\begin{array}{c}\text { Veri Toplama Araçları ve Veri Analiz } \\
\text { Yöntemleri }\end{array}$ & $\mathrm{f}$ & $\%$ \\
\hline Alan yazın & 1 & ,7 & Duygu analizi & 5 & 3,7 \\
\hline Anket & 6 & 4,4 & Görüşme & 8 & 5,9 \\
\hline Anket ve deney & 1 & ,7 & Görüşme ve içerik analizi & 2 & 1,5 \\
\hline Anket ve görüşme & 2 & 1,5 & Gözlem ve görüşme & 1 & ,7 \\
\hline Anket ve içerik analizi & 2 & 1,5 & İçerik analizi & 20 & 14,8 \\
\hline Anket ve odak grup görüşmesi & 1 & ,7 & İçerik analizi, söylem analizi odak grup görüşmesi & 1 & ,7 \\
\hline Anket ve ölçek & 57 & 42,2 & Ölçek & 1 & ,7 \\
\hline Anket, ölçek ve görüşme & 8 & 5,9 & Ölçek ve görüşme & 2 & 1,5 \\
\hline Anket, ölçek ve içerik analizi & 6 & 4,4 & Ölçek ve içerik analizi & 1 & ,7 \\
\hline $\begin{array}{l}\text { Anket, ölçek ve odak grup } \\
\text { görüşmesi }\end{array}$ & 1 & ,7 & Sosyal ağ analizi & 1 & ,7 \\
\hline Büyük veri analizi & 1 & ,7 & Söylem analizi & 3 & 2,2 \\
\hline Deney ve içerik analizi & 1 & ,7 & Tanımsal istatistik & 1 & ,7 \\
\hline Deneysel & 1 & ,7 & Veri madenciliği & 1 & ,7 \\
\hline
\end{tabular}

Tablo 6 sosyal medya konulu doktora tezlerinde kullanılan veri toplama araçları ve veri analiz yöntemlerinin dağılımını yansıtmaktadır. Buna göre ilk sırada $\% 42,2$ ile anket ve ölçeklerin bir arada kullanıldığ 1 çalışmalar gelmektedir. İkinci sırada \%14,8 ile içerik analizi gelmekte, üçüncü sırada ise \%5,9 ile görüşme tekniği gelmektedir. Genel olarak bakıldığında anket tekniğinin gerek tek başına gerekse yanı sıra kullanılan diğer teknik ve veri analiz yöntemleri ile (deney, görüşme, içerik analizi, ölçek, odak grup görüşmesi) birlikte en çok kullanılan teknik (\%62) olduğu görülmektedir. Benzer durum içerik analizleri ve görüşme teknikleri için de geçerlidir. 
Tablo 7. Kullanılan araştırma yöntemlerinin anabilim dallarına göre dağılımı

\begin{tabular}{|c|c|c|c|c|}
\hline \multirow{2}{*}{ Anabilim Dalı } & \multicolumn{3}{|c|}{ Yöntem } & \multirow{2}{*}{ Toplam } \\
\hline & Karma & Nicel & Nitel & \\
\hline Batı Dil ve Edebiyatı & 1 & 0 & 0 & 1 \\
\hline Beden Eğitimi ve Spor Öğretmenliği & 0 & 1 & 0 & 1 \\
\hline Bilgisayar Mühendisliği & 0 & 0 & 2 & 2 \\
\hline Bilgisayar ve Öğretim Teknolojileri & 2 & 0 & 1 & 3 \\
\hline Çalışma Ekonomisi ve Endüstri İlişkileri & 0 & 0 & 1 & 1 \\
\hline Çeviribilim & 0 & 1 & 0 & 1 \\
\hline Eğitim Bilimleri & 1 & 1 & 0 & 2 \\
\hline Ekonometri & 0 & 0 & 1 & 1 \\
\hline Felsefe ve Din Bilimleri & 0 & 1 & 2 & 3 \\
\hline Gazetecilik & 1 & 5 & 4 & 10 \\
\hline Halkla İlişkiler ve Tanıtım & 7 & 9 & 10 & 26 \\
\hline İletişim Bilimleri & 2 & 5 & 3 & 10 \\
\hline İlköğretim & 1 & 1 & 1 & 3 \\
\hline İşletme & 2 & 29 & 6 & 37 \\
\hline Psikoloji & 0 & 0 & 1 & 1 \\
\hline Radyo Televizyon Sinema & 2 & 2 & 4 & 8 \\
\hline Reklamcilık & 0 & 1 & 0 & 1 \\
\hline Sağlık Kurumları İşletmeciliği & 0 & 1 & 0 & 1 \\
\hline Sanat ve Tasarım & 0 & 2 & 0 & 2 \\
\hline Siyaset Bilimi ve Kamu Yönetimi & 0 & 1 & 5 & 6 \\
\hline Sosyoloji & 0 & 3 & 2 & 5 \\
\hline Turizm İşletmeciliği & 1 & 5 & 0 & 6 \\
\hline Uluslararası Güvenlik & 1 & 0 & 0 & 1 \\
\hline Uluslararası İlişkiler ve Siyaset & 1 & 0 & 0 & 1 \\
\hline Yabanc1 Diller & 0 & 0 & 1 & 1 \\
\hline Yönetim Bilgi & 0 & 0 & 1 & 1 \\
\hline Toplam & 22 & 68 & 45 & 135 \\
\hline
\end{tabular}

Tablo 7'de tezlerde kullanılan araştırma yöntemlerinin (nicel, nitel, karma) anabilim dallarına göre dağılımı ortaya konmuştur. Karma yöntemlerin en çok kullanıldığ 1 anabilim dallarının başında 7 tez çalışması ile Halkla İlişkiler ve Tanıtım Anabilim Dalı gelmekte, daha sonra 2'şer tez çalışması ile Bilgisayar ve Öğretim Teknolojileri Anabilim Dalı, İletişim Bilimleri Anabilim Dalı, İşletme Anabilim Dalı ve Radyo Televizyon ve Sinema Anabilim Dalı gelmektedir.

Nicel yöntemlerin en çok kullanıldığı anabilim dallarının başında 29 tez ile İşletme, 9 tez ile Halkla İlişkiler ve Tanıtım ve 5'er tez çalışması ile Gazetecilik, İletişim Bilimleri ve Turizm İşletmeciliği Anabilim Dalları gelmektedir. Nitel yöntemlerin en çok kullanıldığ anabilim dallarının başında ise 10 tez ile Halkla İlişkiler ve Tanıtım, 6 tez ile İşletme ve 5 tez ile de Siyaset Bilimi ve Kamu Yönetimi Anabilim Dalları gelmektedir.

Sosyal medya konusunda en fazla doktora tezinin hazırlandığ İşletme anabilim dalında yine yöntem olarak en fazla (29 tez çalışmasında \%78,4 oranında) nicel yöntemlerin tercih edildiği göze çarparken, Halkla İlişkiler ve Tanıtım Anabilim Dalı'nda en fazla (10 tez çalışmasında \%38,5 oranında) nitel yöntemlerin tercih edildiği, üçüncü sırada gelen iletişim Bilimleri Anabilim Dalı'nda hazırlanan tezlerin yarısında (5 tez çalışmasında \%50 oranında) yine nicel yöntemlerin tercih edildiği görülmektedir. 
Tablo 8. Doktora tezlerinde kullanılan veri toplama araçları ve veri analiz yöntemlerinin araştırma yöntemlerine göre dağılımı

\begin{tabular}{|c|c|c|c|c|}
\hline \multirow{2}{*}{ Veri Toplama Araçları ve Veri Analiz Yöntemleri } & \multicolumn{3}{|c|}{ Araştırma Yöntemleri } & \multirow{2}{*}{ Toplam } \\
\hline & Karma & Nicel & Nitel & \\
\hline Alan yazın & 0 & 0 & 1 & 1 \\
\hline Anket & 0 & 6 & 0 & 6 \\
\hline Anket ve deney & 0 & 1 & 0 & 1 \\
\hline Anket ve görüşme & 2 & 0 & 0 & 2 \\
\hline Anket ve içerik analizi & 2 & 0 & 0 & 2 \\
\hline Anket ve odak grup görüşmesi & 1 & 0 & 0 & 1 \\
\hline Anket ve ölçek & 0 & 57 & 0 & 57 \\
\hline Anket, ölçek ve görüşme & 6 & 2 & 0 & 8 \\
\hline Anket, ölçek ve içerik analizi & 6 & 0 & 0 & 6 \\
\hline Anket, ölçek ve odak grup görüşmesi & 1 & 0 & 0 & 1 \\
\hline Büyük veri analizi & 0 & 0 & 1 & 1 \\
\hline Deney ve içerik analizi & 1 & 0 & 0 & 1 \\
\hline Deneysel & 0 & 1 & 0 & 1 \\
\hline Duygu analizi & 0 & 0 & 5 & 5 \\
\hline Görüşme & 0 & 0 & 8 & 8 \\
\hline Görüşme ve içerik analizi & 0 & 0 & 2 & 2 \\
\hline Gözlem ve görüşme & 0 & 0 & 1 & 1 \\
\hline İçerik analizi & 1 & 0 & 19 & 20 \\
\hline İçerik analizi söylem analizi odak grup & 0 & 0 & 1 & 1 \\
\hline Ölçek & 0 & 1 & 0 & 1 \\
\hline Ölçek ve görüşme & 1 & 0 & 1 & 2 \\
\hline Ölçek ve içerik analizi & 1 & 0 & 0 & 1 \\
\hline Sosyal ağ analizi & 0 & 0 & 1 & 1 \\
\hline Söylem analizi & 0 & 0 & 3 & 3 \\
\hline Tanımsal istatistik & 0 & 0 & 1 & 1 \\
\hline Veri madenciliği & 0 & 0 & 1 & 1 \\
\hline Toplam & 22 & 68 & 45 & 135 \\
\hline
\end{tabular}

Tablo 8 sosyal medya konulu doktora tezlerinde kullanılan veri toplama araçları ve veri analiz yöntemlerinin araştırma yöntemlerine göre dağılımını göstermektedir. Karma yöntem içerisinde en fazla (6 çalışma) "anket, ölçek ve görüşme" teknikleri ile birlikte, yine (6 çalışma) "anket, ölçek ve içerik analizi"nin kullanıldığg dikkat çekmektedir. Nicel yöntemler içerisinde çoğunlukla (57 çalışmada) "anket ve ölçek” tekniklerinin bir arada kullanıldığı görülürken, nitel yöntemler içerisinde en fazla (19 çalışmada) içerik analizinin kullanıldığı, bunu görüşme ve duygu analizinin takip ettiği görülmektedir.

İncelenen tezlerin konu başlıkları içerisinde sosyal medya kavramı ile ilişkili olarak en fazla kullanılan kavramlar en sıktan başlanarak sıralandığında; internet, strateji uygulamaları, pazarlama, satın alma davranışları, siyasal iletişim, kurumsal iletişim, toplumsal olaylar, marka değeri, moda, model, reklamcılık, öğrenme, bilgi edinme, eğitim, dil öğrenimi, alg1 yönetimi, din, kimlik sunumu, sanat, müşteri memnuniyeti, sağlık, turizm şeklindedir. Özellikle en sık kullanılan üç kavramın (internet, strateji uygulamaları, pazarlama) aynı zamanda sosyal medya konusunda en sık çalışılan alanların başında gelen (tablo 7'de görüldüğü gibi) işletme ile ilgili oldukları söylenebilir.

\section{Tartışma ve Sonuç}

İletişim teknolojilerinde ortaya çıkan yeniliklere bağlı olarak araştırma konu ve kapsamları da hem nicel hem nitel açıdan genişlemektedir. İletişim teknolojilerinin gelişmesi sadece kendi alanına özgü kalmamakta, bu genişleme farklı bilim dallarının da konusu olabilmekle birlikte birey ve toplum yaşamını da doğrudan etkilemektedir. Sosyal medya konusundaki çalışmaların yıllar içerisinde genişleyen bir yelpazeye dönüştüğü görülmektedir. 
Bu araştırmada Türkiye'de sosyal medya konulu doktora tezleri; üniversite, anabilim dalı, konu, yıl, araştırma yöntem ve teknikleri değişkenleri açısından incelenmiştir. Konuyla ilgili olarak Yüksek Öğretim Kurulu'nun Ulusal Tez Merkezi'nde erişim izni verilmiş doktora tezleri ele alınmıştır.

Türkiye'de sosyal medya kullanımının 2010'lu yıllara doğru yaygınlaşmasıyla birlikte bu konuda ilk doktora çalışmalarının 2011 yılında, eğitim öğretim, reklamcılık ve halkla ilişkiler alanlarında yapıldığı tespit edilmiş ve 2019 sonu itibarıyla toplam 148 adet doktora tezinden 135 tezin erişime açık olduğu görülmüştür. Aynı şekilde başlığında sosyal medya yer alan ilk yüksek lisans tez çalışmaları da 2010 yılında yine halkla ilişkiler, işletme ve gazetecilik alanlarında yapılmıştır (www.tez.yok.gov.tr: erişim: 10/01/2020). Zaman aralığının (2011-2019) çok geniş olmaması ve erişime açık doktora tezlerinin sayısının örneklem oluşturmada yeterli görülmesi nedeniyle herhangi bir sınırlandırmaya gerek duyulmamıştır. Bu anlamda öncelikle üniversite bazında, Türkiye'de bu konuda en fazla doktora tezinin Marmara Üniversitesi'nde (17 tez \%12,6) yayınlandığ tespit edilmiştir. Marmara Üniversitesinin iletişim fakültesi kuruluşu açısından en eski kurumlardan biri olması bunun önemli nedenlerinden kabul edilebilir. Marmara Üniversitesi İletişim Fakültesi 1948 yılında "İstanbul Gazetecilik Okulu" adıyla ilk gazetecilik okulu olarak kurulmuş, 1982 yılında "Basın yayın Yüksekokulu" adını almış ve 1992 yılında İletişim fakültesine dönüştürülmüş̧ür (www.marmara.edu.tr, 2020). İkinci sırada gelen (15 tez ile \%11,1 oranında) Selçuk Üniversitesi de iletişim alanındaki anabilim dalı çeşitlilikleri açısından Türkiye'de önemli bir yere sahiptir. Üçüncü sırada yer alan (14 tez ile \%10,4 oranında) İstanbul Üniversitesi İletişim Fakültesi ilk olarak 1950 yılında İstanbul Üniversitesi İktisat Fakültesi’ne bağl1 “Gazetecilik Enstitüsü” olarak kurulmuştur. 1980 yılından itibaren Yüksekokul statüsüne kavuşmuş, 1982 yılında Basın Yayın Yüksekokulu adı ile faaliyetini sürdürmüş ve eğitim süresi de dört yıla çıkarılmıştır. 1992 yılında İstanbul Üniversitesi İletişim Fakültesi adını almıştır (www.istanbul.edu.tr, 2020). 1950 yılında İstanbul Üniversitesi, İktisat Fakültesi'nde Gazetecilik Enstitüsü’nün kurulmasıyla başlayan çalışmaları 1965 yılında Ankara Üniversitesi Siyasal Bilgiler Fakültesi Basın Yayın Yüksek Okulu'nun (BYYO) kurulmasıyla devam eden çalışmalar izlemiştir. Sonraki yıllarda iletişim eğitimiyle ilgili eğitim kurumları peş peşe kurulmuştur (Tokgöz, 2000, s. 25).

İlk üç sıradaki üniversitelerin iletişim fakültelerinin kuruluş tarihlerinin gerek daha eskiye dayanması gerekse iletişim alanına ait anabilim dalları çeşitliliğine sahip olmaları yapılan çalışmalarda öncü olmalarında önemli bir rol oynamaktadır. Davulcu ve Tanyeri'nin iletişim alanındaki doktora tezleri ile ilgili yaptıkları benzer bir araştırmada 2006-2016 yılları arasında $\% 28,5$ oranı ile en çok Marmara Üniversitesi’nde doktora tezi hazırlandığ görülürken, Marmara Üniversitesi'ni \%17 ile İstanbul Üniversitesi, \%14,5 ile Ege Üniversitesi takip etmiştir (Davulcu ve Tanyeri, 2018: 59). Sosyal medya konulu tezlerin y1llara göre dağ 1 lımında; ilk tezin tamamlandığ 2011 yılından (\%2,2) itibaren 2016 ve 2017 yılları istisna olmak üzere her geçen yıl artarak sürdügü ve 2019 yılı itibarıyla da en yüksek orana $(\% 27,4)$ ulaştı̆̆ı görülmüştür.

Doktora tezlerinin alanlara göre dağılımına bakıldığında; \%28,1'inin İssletme alanında, \%19'3'ünün Halkla İlişkiler ve Tanıtım alanında, \%7,4'ünün İletişim Bilimleri ve yine \%7,4'ünün Gazetecilik alanında hazırlandığı tespit edilmiştir. Gazetecilik, halkla ilişkiler ve tanıtım, radyo-televizyon ve sinema, reklamcılık gibi anabilim dallarının tümü iletişim bilimleri kapsamında değerlendirilirse oran \%41,1 olmaktadır. Bu anlamda sosyal medya konulu doktora tezlerinin büyük çoğunluğunun $(\% 68,8)$ iletişim ve işletme şeklinde iki alanda toplandığ1 görülmektedir.

Enstitülere göre dağılım incelendiğinde; ilgili konuda hazırlanan tezlerin \%90,4'ünün Sosyal Bilimler Enstitüsü bünyesinde, \%5,9'unun ise Eğitim Bilimleri Enstitüsü bünyesinde toplandıkları görülmüştür. Fen Bilimleri Enstitüsü’nde \%2,2, Güvenlik Bilimleri Enstitüsü’nde ise \%0,7 oranında çalışılmıştır. Sosyal medyanın az da olsa diğer enstitüler bünyesinde çalışıımış olması konunun aslında gündelik yaşamın giderek her alanına yayıldığını göstermesi açısından anlamlı görülmektedir. 
Araştırma yöntemleri açısından bakıldığında sosyal medya konulu doktora tezlerinde çoğunlukla nicel yöntemlere yer verildiği görülmektedir. Bu sonuç Davulcu ve Tanyeri'nin (2018) Türkiye'de 2006-2016 yılları arasında iletişim alanında yapılan doktora tezlerinde kullanılan araştırma yöntemlerinde en çok nitel yöntemlere başvurulduğu şeklindeki sonuçlarıyla farklılaşmaktadır. Bu anlamda kavramsal bakımdan iletişim alanının sosyal medya alanından çok daha geniş olduğunun da göz önünde bulundurulması önemlidir. Sosyal medyanın insan davranışları üzerindeki belirleyiciliğinin somut şekilde daha gözlemlenebilir hale gelmesi, nicel araştırmalarla bu davranışların nedenlerine ilişkin nesnel ve genellenebilir sonuçlar ortaya koyma çabalarını da artırabilir. Ayrıca birey ve gruplar arasında karşılaştırmalar yapma özelliği ile kuramların doğruluk dereceleri de saptanabilir. Neuman' a (2016, s. 224-232) göre, nitel araştırma yapanlar genellikle yorumlayıcı ya da eleştirel sosyal bilime güvenirken nicel araştırmaya yönelenler ise genelde pozitivist yaklaşıma güvenirler. Yine nitelciler olay ve bağlamların dilini konuşurken, nicelciler değişkenlerin ve hipotezlerin dilini konuşurlar. Nicel ve nitel araştırma yapanların birçok ortak yönleri olsa da çalışma tasarımlarında bir tasarımsal mantık kullanmaları, doğrusal/doğrusal olmayan bir yol seçmeleri, bir araştırma sorusu geliştirerek bir doğrulama biçimi kullanmaları konularında tasarımsal farklılıklar gösterirler.

Nicel araştırma yöntemleri, verileri istatistiki süreçlere dayandıran (Erdoğan, 2013), ölçülebilir ve karşılaştırılabilir bir veri topluluğu yoluyla açıklamalara ulaşmayı hedefleyen yöntemlerdir. Nitel yöntemler ise saha araştırması, yaşam öyküsü, tanıklık gibi teknikleri ön plana alan ve çok sayıda verinin toplanması ve analizinden ziyade özel vakaların incelenmesiyle ilgilenen yöntemlerdir (Riutort, 2015, s. 32). İletişim alanında niceliksel araştırmaların dünyaya yayılması 1970'lerde “kullanımlar ve doyumlar" araştırmalarıyla olmuştur (Erdoğan, 2013, s. 200).

Neuman (2016), nitel ve nicel araştırma teknikleri arasındaki farkları şöyle ifade etmektedir: Nicel araştırma tekniklerinde araştırmacının araştırmaya başlarken oluşturduğu hipotez(ler) test edilir ve kavramlar farklı değişkenler halindedir. Nitel araştırmalarda ise araştırmacılar verilere bağlı olarak bir anlam yakalarken, kavramlar bir tema, motif, genelleme veya taksonomi biçimindedirler. Nicel araştırmalarda veriler kesin ölçümlerden hareketle elde edilen sayılara dayanırken, nitel araştırmalarda veriler, belge, gözlem ve yazıya dökülmüş konuşmalardan sözcükler ve imgeler şeklindedir. Nicel araştırmalarda kuram çoğunlukla nedensel ve tümdengelimselken, nitel araştırmalarda kuram nedensel olmayabilir ve tümevarımcıdır. Son olarak nicel araştırmalarda analizler tablo, şekil veya çizelgeler kullanılarak, bunların gösterdikleri hipotezlerle ilişkilendirilir. Nitel araştırmalarda ise analiz, kanıtlardan belli temalar veya genellemeler çıkararak tutarlı, anlaşılır bir bütün oluşturacak şekilde düzenleyerek ilerler (Neuman, 2016, s. 233). Nicel araştırmalar uzun zaman deneysel tasarımlar çerçevesinde gerçekleştirilmiştir ve bu çalışmaların amaçları, belirli bir nüfus içerisinde sosyal olguların sıklıklarını ve dağılımlarını belgelemek ve analiz etmekti (Seggie ve Bayyurt, 2017, s. 14).

Araştırmalarda amaç ortaya konulan soruların, birtakım sistematik prosedürler çerçevesinde cevaplarını bulmaktır. Nitel araştırmalarda düzenli şekilde farklı sosyal ortamlar ve bu ortamları oluşturan grup veya bireyler incelenerek cevaplar aranır. Nitel çalışmalar olaylar arasındaki örüntüleri ararken bu olayları ortalamaya indirmezler. Kısacası nitel araştırmalar araştırmacıların diğer bireylerin algı ve anlayışlarından pay almalarına ve insanların günlük yaşamlarını nasıl şekillendirerek anlam verdiklerini de keşfetmelerine imkan sağlamaktadırlar. Buna karşın nicel araştırmalarda genel fikir ve davranış örüntülerinin tekil özgünlüğe tercih edilmesi nitele karşı avantajlarından birisidir (Berg ve Lune, 2019, s. 20).

Yıldırım (1999) nitel araştırmanın tanımını yaparken içeriğinde veri toplama yöntemleri olarak gözlem, görüşme, doküman incelemesi ve içerik analizi gibi yöntemlerin yer aldığını ve olayların ortaya konmasında bütüncül yaklaşıma yönelik bir süreç izlendiğini belirtmektedir. Yani nitel araştırmalar, sosyal olguları teori oluşturma temelinde bir anlayış ile içinde bulundukları çevrede araştırma ve anlamaya dayalı bir yaklaşımdır. Bu tanımda teori 
oluşturma, toplanan bilgilerden hareketle önceden bilinmeyen birtakım sonuçları birbiriyle ilişkisi içerisinde açıklayan bir modelleme çalışması anlamına gelmektedir. $\mathrm{Bu}$ da araştırmacının hem esnek olmasını hem de toplanan bilgilere göre araştırma sürecini tekrar şekillendirmesini ve gerek araştırma deseninin oluşmasında gerekse toplanan bilgilerin analizinde tümevarıma dayalı bir yaklaşım izlemesini gerektirmektedir (Yıldırım, 1999, s. 10). Nitel çalışma, herhangi bir konuda gerekli verileri toplayan, bunları neden sonuç ilişkisinde analize tabi tutarak birtakım sonuçlara ulaşan bir araştırma biçimi olarak sosyal bilimlerdeki en köklü araştırma türüdür (Erdoğan, 2013, s. 14). Karma yöntem ise nicel ve nitel verilerin birlikte toplandığı, birbirleriyle bütünleştirildiği ardından bu iki veri setini bütünleştirmenin avantajlarının kullanılılarak sonuçlar çıkarıldığı bir araştırma yaklaşımıdır (Creswell, 2019, 2).

Sosyal medya konulu doktora tezlerinde en çok kullanılan araştırma teknikleri ve veri analiz yöntemlerinin anket, ölçek, içerik analizi ve görüşme şeklinde sıralandığı belirtilebilir. Bu teknik ve yöntemlerin tercih edilmelerinde ilgili araştırma türleri önemlidir. Tablo 3 'te görüldügü üzere sosyal medya konularında en çok araştırmalar işletme, halkla ilişkiler, iletişim bilimleri ve gazetecilik alanlarında yapılmıştır. İletişim alanlarında genellikle sosyal medyanın bireyler açısından kullanım durumları ile çeşitli değişkenler karşılaştırılmıştır. Bu konularda anket ve ölçek tekniklerinin veri toplamada öncelikli tercih edildiği ve sosyal medya platformlarına ilişkin içerik analizlerinin de yine sık kullanıldığı söylenebilir. Aynı şekilde işletme alanında sosyal medyanın ekonomik ve ticari yönleri üzerinde yapılan çalışmaların ön planda olduğu görülmüştür. Günümüzde yeni iletişim teknolojilerinin sağladığı olanaklardan ve sosyal medya platformlarının etki alanından yararlanarak birçok şirket halkla ilişkiler ve pazarlama faaliyetlerini etkin bir biçimde kullanmaya ve marka stratejileri geliştirmeye yönelmektedirler (Alp, 2019, s. 40).

Sosyal medyanın gücünü keşfeden ticaret dünyası bireylerin özelliklerini derinlemesine öğrenmeye çalışarak hâkimiyet ve taleplerini bireylere adeta kabul ettirerek egemenliğini ve tüketim tabanlı kültürünü sürdürmek istemektedir (Dilmen, 2012, s. 131). Sosyal ağlar üzerinde kullanıcılar birbirleriyle etkileşime girerlerken bu ortamdan işletmeler de yararlanmak amacıyla çeşitli firsatlar yaratmaktadırlar. Geçmiş yıllarda bir ürün satın alınırken sadece satıcıların istekleri ve üretim tercihleri doğrultusunda şekillenen ürün çeşitleri günümüzde tüketicilerin istekleri doğrultusunda üretilmektedir (Dilmen, 2012, s. 150). Sosyal medyayı kullanan kurum ve kuruluşların neredeyse tümü kendi hedef kitleleriyle, onların düşüncelerini anında öğrenmeye yönelik sohbet ortamları oluşturmaya başlamışlardır (Özgen, 2012, s. 13). İncelenen tezlerin konu başlıkları içerisinde sosyal medya kavramı ile ilişkili olarak en fazla kullanılan üç kavram; internet, strateji uygulamaları ve pazarlama olmuştur. Bu kavramlarla ilişkili olarak işletme alanı sosyal medya konulu doktora tezlerinde en çok çalışılan alanların başında gelmektedir.

Birey ve toplum hayatında giderek daha fazla yer edinmesine bağlı olarak bu konu ile ilgilenen bilim dallarının da çeşitlendiği ve buna bağlı olarak araştırma yöntem ve tekniklerinde de aynı yönde bir artışın olduğu belirtilebilir. Bu araştırmanın konu ile ilgili araştırma yapmak isteyenlere gerek alan gerekse kullanılacak yöntem ve teknikler konusunda belli bir fikir vermesi beklenmektedir. Araştırma 2011-2019 yılları aralığında erişime açık doktora tezleri ile sınırlıdır. Sosyal medyanın birey ve toplum yaşamında her geçen gün etkisini daha fazla gösterdiği göz önüne alınarak, farklı değişkenler çerçevesinde yeni çalışmalar yapılması önerilebilir.

\section{Kaynakça}

Alp, H. (2019). Algı inşasında sosyal medyanın gücü. İstanbul: Kriter Yay.

Ateş, K. E. (2016). Bir bilim dalı olarak iletişim bilimleri alanının Türkiye'deki konusal kapsam analizi. The Journal of Academic Social Science Studies (JASSS), 51(3), 217-228. 
Bayraktutan, G. (2014). Tavır, merak, araç: doğru yol boyunca yürümek. M. Binark (Ed), Yeni Medya Çalışmalarında Araştırma Yöntem ve Teknikleri içinde (ss. 9-14). İstanbul: Ayrıntı Yay.

Berg, B. L. ve Lune, H. (2019). Sosyal bilimlerde nitel araştırma yöntemleri. (A. Arı, Çev.). Konya: Eğitim Yay.

Binbaşıŏlu, H., Deste, M. ve Ünal, A. (2015). Kurumsal iletişim aracı olarak sosyal medya: Türkiye'deki konaklama işletmelerinin sosyal medya çalışmaları üzerine bir araştırma, Turgut Özal Uluslararası Ekonomi ve Siyaset Kongresi 3, İnönü Üniversitesi, Malatya.

Creswell, J. W. (2019). Karma yöntem araştırmalarına giriş. (M. Sözbilir, Çev.). Ankara: Pegem Akademi Yay.

Çalık, M. (2019). Alanyazın tarama. H. Özmen ve O. Karamustafaoğlu (Ed), Eğitimde araştırma yöntemleri içinde (ss. 19-41). Ankara: Pegem Akademi Yay.

Çalık, M. ve Sözbilir M. (2014). İçerik analizinin parametreleri. Eğitim ve Bilim, 39(174), 3338.

Davulcu, E. ve Tanyeri, M. E. (2018). İletişim Araştırmalarında 2006-2016 yılları arasında yapılan doktora tezlerine ilişkin bir durum değerlendirmesi. Karadeniz Teknik Üniversitesi İletişim Araştırmaları Dergisi, 5(15), 55-73.

Dilmen, N. E. (2012). Sosyal paylaşım ağlarının reklam ve pazarlama disiplinleri içerisinde kullanımı. T. Kara ve E. Özgen (Ed), Sosyal Medya/Akademi içinde (ss. 129-154). İstanbul: Beta Yay.

Erdoğan, İ. (2013). Türkiye'de İletişim Araştırmaları. E. Yüksel (Ed), İletişim Kuramları içinde (ss. 184-219). Eskişehir: Anadolu Üniversitesi Yay.

Esen, F. S. (2019). Dumandan Sosyal Medyaya. Ankara: Gazi Yayınları.

İstanbul Üniversitesi. (2020). https://iletisim.istanbul.edu.tr/tr/content/fakultemiz/tarihce Erişim tarihi: 20.01.2020.

Kızıltepe, Z. (2017). Alan yazın derlemesi. F. N. Seggie ve Y. Bayyurt (Ed), Nitel Araştırma içinde (ss. 36-42). Ankara: Anı Yay.

Marmara Üniversitesi. (2020). https://iletisim.marmara.edu.tr/fakulte/tarihce Erişim tarihi: 20.01.2020.

McLuhan, M. (1962). Gutenberg Galaxy: The Making of Typographic Man, University of Toronto Press, Canada.

Neuman, W. L. (2016). Toplumsal araştırma yöntemleri, nicel ve nitel yaklaşımlar. Ankara: Yayın Odas1 Yayınları.

Özgen, E. (2012). Sosyal medya ve halkla ilişkilerde değişen medya anlayışı. T. Kara ve E. Özgen (Ed), Sosyal Medya/Akademi içinde (ss. 9-20). İstanbul: Beta Yay.

Poyraz, E. (2016). Sistem kuranı bağlamında sosyal medyanın iletişim sürecine etkisi. A. Büyükaslan, A. M. Kınık (Ed), Sosyal Medya Araştırmaları II içinde (ss. 61-91). Konya: Çizgi Yay.

Riutort, P. (2015). Sosyolojiye giriş dersleri (E. C. Gürcan, Çev.). Ankara: Doğubatı Yay.

Seggie, F. N. ve Bayyurt, Y. (2017). Nitel araştırma yöntemi. F. N. Seggie ve Y. Bayyurt (Ed), Nitel Araştırma içinde, (ss. 11-22). Ankara: Anı Yay.

Song, I., Larose. R., Eastin, M. S. ve Lin, C. A. (2004). Internet gratifications and internet addiction: on the uses and abuses of new media, CyberPsychology \& Behavior, 7(4), 384394. 
Tokgöz, O. (2000). Türkiye'de iletişim araştırması: nereden nereye. Kültür ve İletişim, 3(2), 1130 .

Yıldırım, A. (1999). Nitel araştırma yöntemlerinin temel özellikleri ve eğitim araştırmalarındaki yeri ve önemi. Eğitim ve Bilim, 23(112), 7-17.

YÖK Ulusal Tez Merkezi (2020). https://tez.yok.gov.tr (Erişim: 16/01/2020) 
Ek Tablo 1. Sosyal medya konulu doktora tezleri listesi

\begin{tabular}{|c|c|c|c|c|}
\hline & Yil & Tez Ad 1 & Hazırlayan & Üniversite \\
\hline 1 & 2011 & $\begin{array}{l}\text { Fakülte - Okul İşbirliği İçin Sosyal Medya Tabanlı Bir } \\
\text { Modelin Geliştirilmesi: Okul Uygulamaları Örneği }\end{array}$ & Selay Arkün & $\begin{array}{l}\text { Hacettepe } \\
\text { Üniversitesi }\end{array}$ \\
\hline 2 & 2011 & $\begin{array}{l}\text { Kurumsal İletişimde Sosyal Medya Yönetimi: Kurumsal } \\
\text { Blog Odaklı Bir İnceleme }\end{array}$ & $\begin{array}{l}\text { Korhan } \\
\text { Mavnacioğlu }\end{array}$ & $\begin{array}{l}\text { İstanbul } \\
\text { Üniversitesi }\end{array}$ \\
\hline 3 & 2011 & $\begin{array}{l}\text { Sosyal Medya Ortamı Olarak Second Life'da Yayınlanan } \\
\text { Reklamların Marka Bilinirliğindeki Rolü }\end{array}$ & $\begin{array}{l}\text { Özge Uluğ } \\
\text { Yurttaş }\end{array}$ & $\begin{array}{l}\text { Marmara } \\
\text { Üniversitesi }\end{array}$ \\
\hline 4 & 2012 & $\begin{array}{l}\text { Ağ Neslinin İnternet Kullanımı Üzerindeki Sosyal Medya } \\
\text { Etkisinin Sosyal Sapma Yaklaşımı İle İncelenmesi }\end{array}$ & $\begin{array}{l}\text { Abdullah } \\
\text { Düvenci }\end{array}$ & $\begin{array}{l}\text { Marmara } \\
\text { Üniversitesi }\end{array}$ \\
\hline 5 & 2012 & $\begin{array}{l}\text { Bir Tutundurma Aracı Olarak Sosyal Medyanın Marka } \\
\text { Bağlılığına Etkileri }\end{array}$ & Yüksel Köksal & $\begin{array}{l}\text { Afyon Kocatepe } \\
\text { Üniversitesi }\end{array}$ \\
\hline 6 & 2012 & $\begin{array}{l}\text { Bireylerin Sosyal Medya Kullanım Davranışlarının Ve } \\
\text { Motivasyonlarının Kullanımlar Ve Doyumlar Yaklaşımı } \\
\text { Bağlamında İncelenmesi: Eskişehir'de Bir Uygulama }\end{array}$ & $\begin{array}{l}\text { N. Gizem } \\
\text { Koçak }\end{array}$ & $\begin{array}{l}\text { Anadolu } \\
\text { Üniversitesi }\end{array}$ \\
\hline 7 & 2012 & $\begin{array}{l}\text { Dijital Platformda Sosyal Medyanın Stratejik Kurumsal } \\
\text { İletişime Etkisi }\end{array}$ & Mikail Bat & Ege Üniversitesi \\
\hline 8 & 2012 & $\begin{array}{l}\text { Pazarlama Halkla İlişkilerinde Sosyal Medya } \\
\text { Uygulamaları }\end{array}$ & $\begin{array}{l}\text { Dilara } \\
\text { Kantemir } \\
\text { Toros }\end{array}$ & $\begin{array}{l}\text { Marmara } \\
\text { Üniversitesi }\end{array}$ \\
\hline 9 & 2012 & $\begin{array}{l}\text { Sosyal Medya Odaklı Bilgi ve İletişim Teknolojilerinin } \\
\text { Kobi Performansına Etkileri: Türkiye'deki İletişim Ve } \\
\text { Reklam Ajansları Üzerine Ampirik Bir Çalışma }\end{array}$ & İkram Daştan & Atatürk Üniversitesi \\
\hline 10 & 2013 & $\begin{array}{l}\text { A Study on Adult EFL Students' Emerging Identities } \\
\text { Within The Context of Social Media Interaction And } \\
\text { Classroom Writing İstanbul Üniversitesi }\end{array}$ & Arzu Ekoç & $\begin{array}{l}\text { İstanbul } \\
\text { Üniversitesi }\end{array}$ \\
\hline 11 & 2013 & $\begin{array}{l}\text { Dijital Platformda Sosyal Markaların İnşası: Markaların } \\
\text { Sosyal Medya Kullanımı Üzerine Bir Araştırma }\end{array}$ & $\begin{array}{l}\text { Duygu Kotan } \\
\text { Türkden }\end{array}$ & $\begin{array}{l}\text { Marmara } \\
\text { Üniversitesi }\end{array}$ \\
\hline 12 & 2013 & $\begin{array}{l}\text { Fen Eğitiminde Harmanlanmış Öğrenme Ve Sosyal } \\
\text { Medya Destekli Öğrenmenin Ögrencilerin Başarı, } \\
\text { Motivasyon, Tutum Ve Kendi Kendine Öğrenme } \\
\text { Becerilerine Etkisi }\end{array}$ & $\begin{array}{l}\text { Devrim } \\
\text { Akgündüz }\end{array}$ & $\begin{array}{l}\text { Marmara } \\
\text { Üniversitesi }\end{array}$ \\
\hline 13 & 2013 & Gözetim Toplumunda Sinoptikon ve Sosyal Medya & Şakir Eşitti & $\begin{array}{l}\text { Marmara } \\
\text { Üniversitesi }\end{array}$ \\
\hline 14 & 2013 & $\begin{array}{l}\text { Sosyal Medya Aracı Olarak Facebook Uygulamalarının } \\
\text { Algılanan Marka Denkliği Boyutlarına Etkisi: GSM } \\
\text { Sektöründe Bir Araştırma }\end{array}$ & Niyazi Gümüş & $\begin{array}{l}\text { Sakarya } \\
\text { Üniversitesi }\end{array}$ \\
\hline 15 & 2013 & $\begin{array}{l}\text { Sosyal Medya Kullanımının "Kurumsal Yenilikçi İtibar" } \\
\text { Üzerindeki Etkisi Üzerine Bir Araştırma }\end{array}$ & $\begin{array}{l}\text { Elif Yurdakul } \\
\text { Coşkunkurt }\end{array}$ & $\begin{array}{l}\text { Marmara } \\
\text { Üniversitesi }\end{array}$ \\
\hline 16 & 2013 & $\begin{array}{l}\text { Sosyal Medya Ortamı Olarak Facebook’un Çekiciliği Ve } \\
\text { Ergenlerde Bağımlılık Düzeyi }\end{array}$ & Yeliz Kuşay & $\begin{array}{l}\text { Marmara } \\
\text { Üniversitesi }\end{array}$ \\
\hline 17 & 2013 & $\begin{array}{l}\text { Sosyal Medya Reklamlarında Tüketici Algılarının } \\
\text { Tutum, Davranış Ve Satın Alma Niyeti Üzerine Etkisi }\end{array}$ & $\begin{array}{l}\text { Duygu Talih } \\
\text { Akkaya }\end{array}$ & Trakya Üniversitesi \\
\hline 18 & 2014 & $\begin{array}{l}\text { Halkla İlişkilerde Hipergerçeklik ve İnternet İlişkisi: } \\
\text { Sosyal Medya Üzerine Bir Araştırma }\end{array}$ & Zühal Akbayır & $\begin{array}{l}\text { Marmara } \\
\text { Üniversitesi }\end{array}$ \\
\hline 19 & 2014 & $\begin{array}{l}\text { İletişim Kaygısının Sosyal Medya Kullanımı Üzerine } \\
\text { Olan Etkisi: Üniversite Öğrencileri Üzerine Örnek Olay } \\
\text { İncelemesi }\end{array}$ & $\begin{array}{l}\text { Veysel } \\
\text { Çakmak }\end{array}$ & Selçuk Üniversitesi \\
\hline 20 & 2014 & İnsan Kaynakları Yönetiminde Sosyal Medyanın Rolü & $\begin{array}{l}\text { Pelin } \\
\text { Vardarlier }\end{array}$ & $\begin{array}{l}\text { Beykent } \\
\text { Üniversitesi }\end{array}$ \\
\hline 21 & 2014 & $\begin{array}{l}\text { Kullanımlar ve Doyumlar Yaklaşımı Açısından Sosyal } \\
\text { Medya Sanal Dünya Oyunu Olarak Second Life Örneği }\end{array}$ & İpek Sucu & $\begin{array}{l}\text { Maltepe } \\
\text { Üniversitesi }\end{array}$ \\
\hline 22 & 2014 & $\begin{array}{l}\text { Marka 2.0 Stratejileri Bağlamında Global Markaların } \\
\text { Sosyal Medyada Gündem Belirlemesi: Markaların } 2.0 \\
\text { Gündemi }\end{array}$ & Emre Ş. Aslan & Gazi Üniversitesi \\
\hline 23 & 2014 & $\begin{array}{l}\text { Sosyal Medya Kullanıcılarının Kişilik Özellikleri, } \\
\text { Kullanım Ve Motivasyonlarının Sosyal Medya } \\
\text { Reklamlarına Yönelik Genel Tutumları Üzerindeki Rolü: } \\
\text { Facebook Üzerine Bir Uygulama }\end{array}$ & Ayşegül Başer & $\begin{array}{l}\text { Marmara } \\
\text { Üniversitesi }\end{array}$ \\
\hline 24 & 2014 & $\begin{array}{l}\text { Sağlık Kuruluşlarında Sosyal Medya Pazarlama } \\
\text { Faaliyetleri İle Memnuniyet, Marka Güveni Ve Marka } \\
\text { Sadakati Arasındaki İlişkinin Belirlenmesine Yönelik Bir } \\
\text { Alan Çalışması }\end{array}$ & Alper Güzel & Gazi Üniversitesi \\
\hline
\end{tabular}




\begin{tabular}{|c|c|c|c|c|}
\hline 25 & 2014 & $\begin{array}{l}\text { Siyaset Ve Sosyal Medya İlişkisi (Ankara Büyükşehir } \\
\text { Belediye Başkanı İbrahim Melih Gökçek Örneği) }\end{array}$ & $\begin{array}{l}\text { İsmail Ayşad } \\
\text { Güdekli } \\
\end{array}$ & $\begin{array}{l}\text { Akdeniz } \\
\text { Üniversitesi }\end{array}$ \\
\hline 26 & 2014 & $\begin{array}{l}\text { Sosyal Medya Kullanımının Müşteri Tercihleri Üzerine } \\
\text { Etkileri: Konaklama İşletmelerinde Bir İnceleme }\end{array}$ & $\begin{array}{l}\text { Burak } \\
\text { Eryilmaz }\end{array}$ & $\begin{array}{l}\text { Sakarya } \\
\text { Üniversitesi }\end{array}$ \\
\hline 27 & 2014 & $\begin{array}{l}\text { Sosyal Medyadaki Ağızdan Ağıza Pazarlama } \\
\text { Faaliyetlerinin Satın Alma Kararları Üzerine Etkileri }\end{array}$ & Esra Güven & $\begin{array}{l}\text { Celal Bayar } \\
\text { Üniversitesi }\end{array}$ \\
\hline 28 & 2014 & $\begin{array}{l}\text { Sosyal Medyanın Toplumsallaşmaya Etkileri: Üniversite } \\
\text { Öğrencileri Örneği }\end{array}$ & Osman Metin & $\begin{array}{l}\text { Afyon Kocatepe } \\
\text { Üniversitesi }\end{array}$ \\
\hline 29 & 2014 & $\begin{array}{l}\text { Sosyal Medyanın Ulus Devletlerin Güvenliklerine } \\
\text { Etkileri: Arap Baharı Ve Gezi Parkı Örneği }\end{array}$ & Kemal İlter & Polis Akademisi \\
\hline 30 & 2015 & $\begin{array}{l}\text { A Discourse Analysis of Communicative Actions of } \\
\text { Strategy Practitioners on Social Media }\end{array}$ & $\begin{array}{l}\text { Ömer } \\
\text { Vatanartıran }\end{array}$ & $\begin{array}{l}\text { İstanbul Bilgi } \\
\text { Üniversitesi }\end{array}$ \\
\hline 31 & 2015 & $\begin{array}{l}\text { Bir Siyasal İletişim Aracı Olarak Sosyal Medya: } \\
\text { Milletvekili Ve Seçmen Örneğinde Bir Alan Araştırması }\end{array}$ & $\begin{array}{l}\text { Mustafa } \\
\text { Bostanc1 }\end{array}$ & Erciyes Üniversitesi \\
\hline 32 & 2015 & $\begin{array}{l}\text { Graduate Students' Use of Social Media Tools For } \\
\text { Thesis/Dissertation Research }\end{array}$ & Murat Duman & ODTÜ \\
\hline 33 & 2015 & $\begin{array}{l}\text { Kamu İdareleri ve Kuruluşlarında Sosyal Medya: } \\
\text { Kavramsal Ve Ampirik Bir Çalışma (Türkiye Örneği) }\end{array}$ & Seyida Erkek & Selçuk Üniversitesi \\
\hline 34 & 2015 & $\begin{array}{l}\text { Küreyerel Fotoğrafa Özdüşünümsel Bir Yaklaşım: Bir } \\
\text { Sosyal Medya Tasarımı }\end{array}$ & $\begin{array}{l}\text { Funda Can } \\
\text { Çuvalcı }\end{array}$ & $\begin{array}{l}\text { Anadolu } \\
\text { Üniversitesi }\end{array}$ \\
\hline 35 & 2015 & $\begin{array}{l}\text { Siyasal İletişim Kampanyalarında Yeni İletişim } \\
\text { Teknolojilerinin Kullanımı: "2015 Genel Seçimleri } \\
\text { Dönemi Web Sayfaları Ve Sosyal Medya Kullanımları" }\end{array}$ & Zühal Fidan & Selçuk Üniversitesi \\
\hline 36 & 2015 & $\begin{array}{l}\text { Siyasal Katılım Sürecinde Sosyal Medyanın Rolü Ve } \\
\text { Etkileri }\end{array}$ & Mustafa İşliyen & Selçuk Üniversitesi \\
\hline 37 & 2015 & $\begin{array}{l}\text { Sosyal Medya Bağımlılı̆̆ı: Üniversite Öğrencileri } \\
\text { Üzerine Bir Araştırma }\end{array}$ & $\begin{array}{l}\text { Aylin Tutgun } \\
\text { Ünal }\end{array}$ & $\begin{array}{l}\text { Marmara } \\
\text { Üniversitesi }\end{array}$ \\
\hline 38 & 2015 & $\begin{array}{l}\text { Sosyal Medya Tercihlerinde Kullanıcıyı Etkileyen } \\
\text { Faktörler }\end{array}$ & $\begin{array}{l}\text { Murat } \\
\text { Dağıtmaç }\end{array}$ & $\begin{array}{l}\text { Y1ldı Teknik } \\
\text { Üniversitesi }\end{array}$ \\
\hline 39 & 2015 & $\begin{array}{l}\text { Sosyal Medya Ve Siyaset İlişkisinin Müzakereci Ve } \\
\text { Agonistik Demokrasi Yaklaşımları Çerçevesinde Analizi: } \\
\text { Türkiye'de } 2014 \text { Cumhurbaşkanlığı Seçimi Sürecinde } \\
\text { Twitter Kullanımı }\end{array}$ & $\begin{array}{l}\text { Kamil } \\
\text { Demirhan }\end{array}$ & $\begin{array}{l}\text { Hacettepe } \\
\text { Üniversitesi }\end{array}$ \\
\hline 40 & 2015 & Sosyal Medyada Din Algısı (Twitter Örneği) & $\begin{array}{l}\text { Lokman } \\
\text { Cerrah }\end{array}$ & Atatürk Üniversitesi \\
\hline 41 & 2015 & $\begin{array}{l}\text { Sosyal Medyanın Kamuoyu Oluşturma Ve Siyasal } \\
\text { katılma Üzerine Etkileri: Kuramsal Ve Ampirik Bir } \\
\text { Analiz }\end{array}$ & Vahap Göksu & Selçuk Üniversitesi \\
\hline 42 & 2015 & $\begin{array}{l}\text { Sosyal Medyanın Viral (Elektronik Ağıddan Ağıza) } \\
\text { Pazarlama Faaliyetleri Ve Tüketici Satın Alım Niyetine } \\
\text { Etkileri }\end{array}$ & $\begin{array}{l}\text { Derya Fatma } \\
\text { Biçer }\end{array}$ & Atatürk Üniversitesi \\
\hline 43 & 2015 & $\begin{array}{l}\text { Sosyal Medyanın Yeni Tür Kamusal Alan Yaratması Ve } \\
\text { Toplumsal Hareketlere Katkıları: Taksim Gezi Parkı } \\
\text { Olayları Örneği }\end{array}$ & Sami Çöteli & $\begin{array}{l}\text { İstanbul } \\
\text { Üniversitesi }\end{array}$ \\
\hline 44 & 2015 & $\begin{array}{l}\text { The Effect of Social Networks on Intercultural } \\
\text { Communication And Awareness: The Facebook Case }\end{array}$ & Doğan Saltaş & $\begin{array}{l}\text { Karadeniz Teknik } \\
\text { Üniversitesi }\end{array}$ \\
\hline 45 & 2015 & $\begin{array}{l}\text { Toplumsal Hareketler Ve Sosyal Medya Kullanımı } \\
\text { Çerçevesinde }\end{array}$ & Asli Advan & $\begin{array}{l}\text { İ̀stanbul } \\
\text { Üniversitesi }\end{array}$ \\
\hline 46 & 2015 & $\begin{array}{l}\text { Toplumsal Hareketlerin Sosyal Medyada } \\
\text { Çerçevelenmesi: Çevre Odaklı STK'lara İlişsin Bir } \\
\text { Söylem Çerçevesi Analizi }\end{array}$ & $\begin{array}{l}\text { Habibe Akçay } \\
\text { Bekiroğlu }\end{array}$ & Gazi Üniversitesi \\
\hline 47 & 2015 & $\begin{array}{l}\text { Turizm Tanıtımında Sosyal Medya Planlamasına Yönelik } \\
\text { Uygulamalı Bir Çalışma: Erciyes Dağı Örneği }\end{array}$ & $\begin{array}{l}\text { Mustafa } \\
\text { CINGI }\end{array}$ & $\begin{array}{l}\text { Erzurum } \\
\text { Üniversitesi }\end{array}$ \\
\hline 48 & 2016 & $\begin{array}{l}7 \text { Haziran’dan } 1 \text { Kasım } 2015 \text { Genel Seçimlerine Siyasal } \\
\text { Karar Ve Katılım Sürecinde Sosyal Medyanın Etkinliği: } \\
\text { Sivas Örneği }\end{array}$ & Onur Taydaş & Selçuk Üniversitesi \\
\hline 49 & 2016 & $\begin{array}{l}\text { GSM Markalarının Sosyal Medya Kullanımlarının Halkla } \\
\text { İlişkilerin Çift Yönlü Simetrik Modeline Göre Twitter } \\
\text { Üzerinden Analizi }\end{array}$ & Ezel TÜRK & $\begin{array}{l}\text { İstanbul } \\
\text { Üniversitesi }\end{array}$ \\
\hline 50 & 2016 & $\begin{array}{l}\text { Online Satış Platformlarında Müşteri İlişkileri } \\
\text { Yönetiminin Performansa Etkisi Üzerinde Sosyal Medya } \\
\text { Kullanımının Rolü: Sosyal Müşteri İlişkileri Yönetimi } \\
\text { (Sosyal Crm) }\end{array}$ & $\begin{array}{l}\text { Nazif Can } \\
\text { Ulucan }\end{array}$ & Haliç Üniversitesi \\
\hline
\end{tabular}




\begin{tabular}{|c|c|c|c|c|}
\hline 51 & 2016 & $\begin{array}{l}\text { Otel İşletmelerinde Sosyal Medyanın Müşteri E-Sadakati } \\
\text { Üzerine Etkisi: Facebook Örneği }\end{array}$ & Fatih Ercan & $\begin{array}{l}\text { Adnan Menderes } \\
\text { Üniversitesi } \\
\end{array}$ \\
\hline 52 & 2016 & $\begin{array}{l}\text { Öğretmen Adaylarının Sosyal Medyadaki Etik } \\
\text { Davranışlara İlişkin Görüşlerinin İncelenmesi: Eskişehir } \\
\text { İli Örneği }\end{array}$ & Özge Misırlı & $\begin{array}{l}\text { Anadolu } \\
\text { Üniversitesi }\end{array}$ \\
\hline 53 & 2016 & Özel Alan Çevirisi Eğitiminde Sosyal Medyanın Etkisi & $\begin{array}{l}\text { Dolunay } \\
\text { Kumlu }\end{array}$ & $\begin{array}{l}\text { İstanbul } \\
\text { Üniversitesi }\end{array}$ \\
\hline 54 & 2016 & $\begin{array}{l}\text { Sağlık İletişimde Sosyal Medyanın Rolü: Türkiye’de } \\
\text { Sağlık Kurumlarının Sosyal Medya Kullanımının } \\
\text { İncelenmesi }\end{array}$ & $\begin{array}{l}\text { Kezban } \\
\text { Karagöz }\end{array}$ & $\begin{array}{l}\text { İstanbul } \\
\text { Üniversitesi }\end{array}$ \\
\hline 55 & 2016 & $\begin{array}{l}\text { Sosyal Medya Kullanım Motivasyonları: Facebook Ve } \\
\text { Twitter Kullanıcıları Üzerine Kullanımlar Ve Doyumlar } \\
\text { Araştırması }\end{array}$ & $\begin{array}{l}\text { Nagihan Tufan } \\
\text { Yeniçıktı }\end{array}$ & Selçuk Üniversitesi \\
\hline 56 & 2016 & $\begin{array}{l}\text { Sosyal Medya Mesajlarında Müssteri Memnuniyetinin } \\
\text { Fuzzy Sentiment Analizi İle Ölçülmesi }\end{array}$ & $\begin{array}{l}\text { Elyase } \\
\text { İskender }\end{array}$ & $\begin{array}{l}\text { Marmara } \\
\text { Üniversitesi }\end{array}$ \\
\hline 57 & 2016 & $\begin{array}{l}\text { Sosyal Medya Paylaşımlarında Duygu Analizi: Makine } \\
\text { Öğrenimi Yaklaşımı Üzerine Bir Araştırma }\end{array}$ & Ümit Topaçan & $\begin{array}{l}\text { Marmara } \\
\text { Üniversitesi }\end{array}$ \\
\hline 58 & 2016 & $\begin{array}{l}\text { Sosyal Medya Sayfalarının Müş̧eri Sermayesi Üzerine } \\
\text { Etkilerinin İncelenmesi }\end{array}$ & Alkan Alkaya & $\begin{array}{l}\text { Dumlupinar } \\
\text { Üniversitesi }\end{array}$ \\
\hline 59 & 2016 & $\begin{array}{l}\text { Stratejik Pazarlama Kararlarında Sosyal Medya } \\
\text { Uygulamalarının Etkisi: Sağlık Sektöründe Bir Araştırma }\end{array}$ & $\begin{array}{l}\text { Sami Onur } \\
\text { Erarslan }\end{array}$ & Okan Üniversitesi \\
\hline 60 & 2016 & $\begin{array}{l}\text { Sosyal Medyanın Hasta Sadakatine Etkisi: Sosyal Medya } \\
\text { Kullanıcıları Üzerine Bir Araştırma }\end{array}$ & Hikmet Tosyalı & $\begin{array}{l}\text { Marmara } \\
\text { Üniversitesi }\end{array}$ \\
\hline 61 & 2016 & $\begin{array}{l}\text { Sosyal Medya Reklamcılığı Ve Etik: Facebook } \\
\text { Reklamları Ve Etik Değerlerdeki Değişim Üzerine Bir } \\
\text { Araştırma }\end{array}$ & Ersin Diker & Selçuk Üniversitesi \\
\hline 62 & 2016 & $\begin{array}{l}\text { Sosyal Medya, İlgilenim Ve Destinasyon Marka Denkliği } \\
\text { Arasındaki İlişki }\end{array}$ & $\begin{array}{l}\text { Bekir Bora } \\
\text { Dedeoğlu }\end{array}$ & $\begin{array}{l}\text { Akdeniz } \\
\text { Üniversitesi }\end{array}$ \\
\hline 63 & 2016 & $\begin{array}{l}\text { Yapısal Olmayan Verilerin Büyük Veri Analiz } \\
\text { Yöntemleri İle İşlenmesi Ve Yapısal Olan Verilerle } \\
\text { İlişkilendirilmesine Yönelik Bir Platform: Sosyal Medya } \\
\text { Temelli Tavsiye Motoru Geliştirme }\end{array}$ & Onur Sevli & $\begin{array}{l}\text { Süleyman Demirel } \\
\text { Üniversitesi }\end{array}$ \\
\hline 64 & 2017 & $\begin{array}{l}\text { Fotoğraf Ve Video Lisans Bölüm Öğrencilerinin Sosyal } \\
\text { Medyadaki Estetik, Plastik Ve Etik Bilinç Yansımasının } \\
\text { İncelenmesi }\end{array}$ & Erkan Çiçek & $\begin{array}{l}\text { Yildız Teknik } \\
\text { Üniversitesi }\end{array}$ \\
\hline 65 & 2017 & $\begin{array}{l}\text { Müşteri Kayıplarını Önlemede Kullanılan Hizmet Telafi } \\
\text { Stratejilerine İlişskin Sonuçların Sosyal Medya Paylaşım } \\
\text { Eğilimi: Türkiye' de Bankalar Üzerine Bir Uygulama }\end{array}$ & $\begin{array}{l}\text { Berrin Arzu } \\
\text { Eren }\end{array}$ & $\begin{array}{l}\text { Anadolu } \\
\text { Üniversitesi }\end{array}$ \\
\hline 66 & 2017 & $\begin{array}{l}\text { Öğretmen Adaylarının Sosyal Medya Kullanma } \\
\text { Durumlarına Göre Çok Kültürlü Eğitime İlişkin Görüşleri }\end{array}$ & $\begin{array}{l}\text { Nesrin Hark } \\
\text { Söylemez }\end{array}$ & Dicle Üniversitesi \\
\hline 67 & 2017 & $\begin{array}{l}\text { Paydaşların Gözünden Sosyal Medyanın Yarar Ve } \\
\text { Risklerine Yönelik Bir İnceleme }\end{array}$ & Türkan Çelik & $\begin{array}{l}\text { Pamukkale } \\
\text { Üniversitesi }\end{array}$ \\
\hline 68 & 2017 & $\begin{array}{l}\text { Sosyal Bilgiler Öğretmenlerinin Eğitimde Sosyal } \\
\text { Medyayı Kullanım Düzeyleri Ve } \\
\text { Görüşleri }\end{array}$ & Erhan Yaylak & $\begin{array}{l}\text { Pamukkale } \\
\text { Üniversitesi2017 }\end{array}$ \\
\hline 69 & 2017 & $\begin{array}{l}\text { Sosyal Medya Mesajlarında Veri Madenciliği İle Duygu } \\
\text { Analizi }\end{array}$ & $\begin{array}{l}\text { Nisa Selcan } \\
\text { Değer }\end{array}$ & $\begin{array}{l}\text { İstanbul } \\
\text { Üniversitesi }\end{array}$ \\
\hline 70 & 2017 & $\begin{array}{l}\text { Sosyal Medya Paradigmasındaki Dönüşümün Siyasal } \\
\text { Katılıma Yansıması }\end{array}$ & $\begin{array}{l}\text { Abdullah } \\
\text { Aydın }\end{array}$ & $\begin{array}{l}\text { Mustafa Kemal } \\
\text { Üniversitesi }\end{array}$ \\
\hline 71 & 2017 & $\begin{array}{l}\text { Sosyal Medya Pazarlamasında Ünlü Onaylayanların } \\
\text { Tüketici Algısı Ve Satın Alma Niyeti Üzerine Etkisi }\end{array}$ & Bihter Çinkay & $\begin{array}{l}\text { Kahramanmaraş } \\
\text { Sütçü İmam } \\
\text { Üniversitesi }\end{array}$ \\
\hline 72 & 2017 & $\begin{array}{l}\text { Sosyal Medyanın Telekomünikasyon Sektörü Halkla } \\
\text { İlişkiler Birimlerinde Kullanımının Önemi: Vataniye Ve } \\
\text { Cevval Şirketlerinin Sosyal Medya Profil Analizi }\end{array}$ & $\begin{array}{l}\text { Hanadi H. S. } \\
\text { Dwikat }\end{array}$ & $\begin{array}{l}\text { İstanbul } \\
\text { Üniversitesi }\end{array}$ \\
\hline 73 & 2017 & $\begin{array}{l}\text { Sosyal Medya Davranışının Oluşumu: Çevrimiçi } \\
\text { Ortamlarda Güven, Sosyal Sermaye Ve Saygınlık İlişkisi }\end{array}$ & $\begin{array}{l}\text { Fatma Ceyda } \\
\text { Baş }\end{array}$ & Selçuk Üniversitesi \\
\hline 74 & 2017 & $\begin{array}{l}\text { Sosyal Medya Kullanım Niyetlerini Etkileyen Faktörlerin } \\
\text { İncelenmesi Üzerine Bir Alan Araştırması }\end{array}$ & $\begin{array}{l}\text { Fatih Sinan } \\
\text { Esen }\end{array}$ & Gazi Üniversitesi \\
\hline 75 & 2017 & $\begin{array}{l}\text { Sosyal Medya Kullanımı Ve Kurumsal Markalaşma: } \\
\text { Vodafone Örneği Üzerinden Bir Alan Araştırması }\end{array}$ & $\begin{array}{l}\text { Ali Fikret } \\
\text { Aydın }\end{array}$ & Gazi Üniversitesi \\
\hline 76 & 2018 & $\begin{array}{l}\text { A Social Media Big Data Mining Framework For } \\
\text { Detectıng Sentiments in Multiple Languages }\end{array}$ & $\begin{array}{l}\text { Mustafa } \\
\text { Coşkun }\end{array}$ & $\begin{array}{l}\text { Boğaziçi } \\
\text { Üniversitesi }\end{array}$ \\
\hline
\end{tabular}




\begin{tabular}{|c|c|c|c|c|}
\hline 77 & 2018 & $\begin{array}{l}\text { Alg1 Yönetimi Ve Sosyal Medya: } 2017 \text { Anayasa } \\
\text { Referandumu Üzerinden Bir İnceleme }\end{array}$ & Emrah Arğın & İnönü Üniversitesi \\
\hline 78 & 2018 & $\begin{array}{l}\text { Bir Tutundurma Aracı Olarak Sosyal Medya } \\
\text { Aktivitelerinin Marka Değerine Etkisi: Türkiye'de Gazlı } \\
\text { İçecek Kategorisi Üzerine Bir Uygulama }\end{array}$ & Semra Alkan & $\begin{array}{l}\text { Beykent } \\
\text { Üniversitesi }\end{array}$ \\
\hline 79 & 2018 & $\begin{array}{l}\text { Bireylerin Moda Giyim İlgilenimi, Sosyal Medya } \\
\text { İlgilenimi Ve Yaşam Tarzı Tiplerinin Satın Alma Niyeti } \\
\text { Ve Ağızdan Ağıa İletişim Davranışına Etkisi Üzerine } \\
\text { Bir Araştırma }\end{array}$ & Aysel Boztepe & $\begin{array}{l}\text { İstanbul Ticaret } \\
\text { Üniversitesi }\end{array}$ \\
\hline 80 & 2018 & $\begin{array}{l}\text { Büyük Veri ve İşletme Analitiği: Sosyal Medya ve } \\
\text { Duygu Analizi İle Bir Öngörü Modeli }\end{array}$ & Burcu Karaöz & $\begin{array}{l}\text { İstanbul } \\
\text { Üniversitesi }\end{array}$ \\
\hline 81 & 2018 & $\begin{array}{l}\text { Dini Kimliklerin Sosyal Medyada Akışkanlaşması: Siber- } \\
\text { Etnografik Bir Araştırma }\end{array}$ & $\begin{array}{l}\text { Mustafa Derviş } \\
\text { Dereli }\end{array}$ & Erciyes Üniversitesi \\
\hline 82 & 2018 & Duygu Analizi Ve Sosyal Medya Alanında Uygulama & $\begin{array}{l}\text { Yusuf Murat } \\
\text { Kizılkaya }\end{array}$ & Uludağ Üniversitesi \\
\hline 83 & 2018 & $\begin{array}{l}\text { Kamu Yönetiminde Sosyal Medya Kullanımı Ve } \\
\text { Yönetimi: Temel İlkeler Ve Öneriler }\end{array}$ & $\begin{array}{l}\text { Taylan } \\
\text { Gülaslan }\end{array}$ & $\begin{array}{l}\text { Hacettepe } \\
\text { Üniversitesi }\end{array}$ \\
\hline 84 & 2018 & $\begin{array}{l}\text { Kamusal Alanda Sosyal Taklit: Sosyal Medyada Yeni } \\
\text { Gelin Evi İmgesi }\end{array}$ & Nuriye Çelik & Selçuk Üniversitesi \\
\hline 85 & 2018 & $\begin{array}{l}\text { Konaklama İşletmelerinin Sosyal Medya Kullanım } \\
\text { Şekillerinin Tüketici Tutum Ve Satın Alma Niyeti } \\
\text { Üzerindeki Etkileri }\end{array}$ & Semih Arıcı & $\begin{array}{l}\text { Sakarya } \\
\text { Üniversitesi }\end{array}$ \\
\hline 86 & 2018 & $\begin{array}{l}\text { Kötülüğün Sıradanlığg Bağlamında Sosyal Medya: } \\
\text { Twitter'da Suriyeli Mülteciler Örneği }\end{array}$ & Ayşe Aldemir & $\begin{array}{l}\text { Marmara } \\
\text { Üniversitesi }\end{array}$ \\
\hline 87 & 2018 & $\begin{array}{l}\text { Kuşakların Sosyal Medya Kullanımının Yiyecek İçecek } \\
\text { İşletmesi Tercihleri Üzerine Etkisi }\end{array}$ & $\begin{array}{l}\text { Mehtap Yücel } \\
\text { Güngör }\end{array}$ & $\begin{array}{l}\text { Adnan Menderes } \\
\text { Üniversitesi }\end{array}$ \\
\hline 88 & 2018 & $\begin{array}{l}\text { Lüks Giyim Markalarında Sosyal Medya İlgilenimi, } \\
\text { Marka Değeri Ve Marka Tercihi İlişkisi }\end{array}$ & $\begin{array}{l}\text { Tuğba } \\
\text { Uzunkaya }\end{array}$ & $\begin{array}{l}\text { Beykent } \\
\text { Üniversitesi }\end{array}$ \\
\hline 89 & 2018 & $\begin{array}{l}\text { Özel Spor Merkezi Üyelerinin Spor İlgilenimi Ve } \\
\text { Algıladıkları Değerin Sosyal Medya Kullanımı Üzerine } \\
\text { Etkisi }\end{array}$ & $\begin{array}{l}\text { Engin Işık } \\
\text { Abanoz }\end{array}$ & $\begin{array}{l}\text { Sakarya } \\
\text { Üniversitesi }\end{array}$ \\
\hline 90 & 2018 & $\begin{array}{l}\text { Siyasal Pazarlama Sürecinde Sosyal Medya Ve } \\
\text { Elektronik Ağızdan Ağıza İletişim }\end{array}$ & Ali Tehci & $\begin{array}{l}\text { Gümüşhane } \\
\text { Üniversitesi }\end{array}$ \\
\hline 91 & 2018 & $\begin{array}{l}\text { Sosyal Medya Bağımlılığının Öğrencilerin } \\
\text { Performanslarına Etkileri Üzerine Bir Araştırma }\end{array}$ & $\begin{array}{l}\text { Eda } \\
\text { Büyükgebiz }\end{array}$ & $\begin{array}{l}\text { Süleyman Demirel } \\
\text { Üniversitesi }\end{array}$ \\
\hline 92 & 2018 & $\begin{array}{l}\text { Sosyal Medya Güvenilirlik Algıısının Bilgi Paylaşma } \\
\text { Davranışıyla İlişkisi: Anadolu Üniversitesi Öğrencileri } \\
\text { Örneği }\end{array}$ & $\begin{array}{l}\text { Mehmet R. } \\
\text { Y1ldıgörür }\end{array}$ & $\begin{array}{l}\text { Anadolu } \\
\text { Üniversitesi }\end{array}$ \\
\hline 93 & 2018 & $\begin{array}{l}\text { Sosyal Medya Paylaşımlarının İçerik Etkisi Ve Bu } \\
\text { Paylaşımlara Olan Tüketici Tepkisinin Metin Madenciliği } \\
\text { Metodu İle Analizi }\end{array}$ & $\begin{array}{l}\text { Abdullah } \\
\text { Önden }\end{array}$ & $\begin{array}{l}\text { İstanbul Okan } \\
\text { Üniversitesi }\end{array}$ \\
\hline 94 & 2018 & $\begin{array}{l}\text { Sosyal Medya Üzerinden Gerçekleşen Öğretmen- } \\
\text { Öğrenci Etkileşiminin Örtük Program Açısından } \\
\text { İncelenmesi }\end{array}$ & Mustafa Demir & İnönü Üniversitesi \\
\hline 95 & 2018 & $\begin{array}{l}\text { Sosyal Medya Ve Toplumsal Hareketler: Gezi Park1 } \\
\text { Protestoları Örneğinde Sosyal Medyanın Kullanımı }\end{array}$ & $\begin{array}{l}\text { Mehmet Melih } \\
\text { Barut }\end{array}$ & Ankara Üniversitesi \\
\hline 96 & 2018 & $\begin{array}{l}\text { Sosyal Medya Ve Sendikalar: Almanya, Fransa, } \\
\text { Hollanda, Polonya Ve Türkiye Örneği Üzerine Bir Sosyal } \\
\text { Ağ Analizi Araştırması }\end{array}$ & Hüseyin Sevgi & Uludağ Üniversitesi \\
\hline 97 & 2018 & $\begin{array}{l}\text { Toplumsal Hareketler Ve Sosyal Medya İlişkisi: Gezi } \\
\text { Parkı Ve Tahrir Meydanı Örnekleri }\end{array}$ & $\begin{array}{l}\text { Turgay } \\
\text { Yerlikaya }\end{array}$ & $\begin{array}{l}\text { Marmara } \\
\text { Üniversitesi }\end{array}$ \\
\hline 98 & 2018 & $\begin{array}{l}\text { Türkiye'de Sosyal Medya Ve Yeni Politika Yapma } \\
\text { Biçimleri }\end{array}$ & Gülcan Ergün & $\begin{array}{l}\text { Anadolu } \\
\text { Üniversitesi }\end{array}$ \\
\hline 99 & 2019 & $\begin{array}{l}\text { Algılanan Sosyal Medya Pazarlama Çabalarının Marka } \\
\text { Değeri Ve Satın Alma Niyeti Üzerine Etkisi: } \\
\text { Tüketicilerin Sosyal Medya Bağı Ve Kullanım Sıklığı } \\
\text { Üzerine Bir Araştırma }\end{array}$ & $\begin{array}{l}\text { Cem } \\
\text { Karayalçın }\end{array}$ & $\begin{array}{l}\text { Akdeniz } \\
\text { Üniversitesi }\end{array}$ \\
\hline 100 & 2019 & $\begin{array}{l}\text { Bir Sosyal Medya Platformu Olarak Instagram Kullanım } \\
\text { Güdüleri: Kullanıcıların Kimlik Sunumu Üzerine Bir } \\
\text { Araştırma }\end{array}$ & $\begin{array}{l}\text { Ezgi } \\
\text { Saatcı̆oglu }\end{array}$ & Yaşar Üniversitesi \\
\hline 101 & 2019 & $\begin{array}{l}\text { Bölücü Terörle Mücadele Ve Toplumsal Duyarlılık } \\
\text { Oluşturmada Sosyal Medya Faktörü: İzmir Polisi Üzerine } \\
\text { Bir Araştırma }\end{array}$ & Hüseyin Aşkın & Gazi Üniversitesi \\
\hline
\end{tabular}




\begin{tabular}{|c|c|c|c|c|}
\hline 102 & 2019 & $\begin{array}{l}\text { Çevre Hareketi Bağlamında Sivil Toplum Örgütlerinin } \\
\text { Sosyal Medya Platformlarında İletişim Süreci: } \\
\text { Greenpeace Ve Wwf Örneği }\end{array}$ & $\begin{array}{l}\text { Zeynep Benan } \\
\text { Dondurucu }\end{array}$ & Kocaeli Üniversitesi \\
\hline 103 & 2019 & $\begin{array}{l}\text { Dijital Alanda Kurumsal Spor İletişimi: Spor Kulüpleri } \\
\text { Ve Taraftarların Sosyal Medya Kullanımları Üzerine } \\
\text { Araştırma }\end{array}$ & Fatih Çelik & Selçuk Üniversitesi \\
\hline 104 & 2019 & $\begin{array}{l}\text { Dini Bilgi Edinme Kaynağı Olarak Sosyal Medya } \\
\text { (İlahiyat Fakültesi Öğrencileri Örneği) }\end{array}$ & İsmail Demir & $\begin{array}{l}\text { Çanakkale Onsekiz } \\
\text { Mart Üniversitesi }\end{array}$ \\
\hline 105 & 2019 & Essays on Social Media, Politics And Misinformation & Simge And1 & Koç Üniversitesi \\
\hline 106 & 2019 & $\begin{array}{l}\text { Geç Modern Dönemde Bireysel Kimliklerin Anlamsal Ve } \\
\text { İşlevsel Değişimi (Sosyal Medya Örneğinde) }\end{array}$ & $\begin{array}{l}\text { Saniye } \\
\text { Vatandaş }\end{array}$ & Atatürk Üniversitesi \\
\hline 107 & 2019 & $\begin{array}{l}\text { Hedonik Alışveriş Motivasyonları Ve Teknoloji Kabul } \\
\text { Modeli Bileşenlerinin Çevrimiçi Satın Alma Niyetine } \\
\text { Etkisi: Sosyal Medya Kullanıcıları Üzerine Bir Araştırma }\end{array}$ & $\begin{array}{l}\text { Selçuk Yasin } \\
\text { Yildız }\end{array}$ & $\begin{array}{l}\text { Çukurova } \\
\text { Üniversitesi }\end{array}$ \\
\hline 108 & 2019 & $\begin{array}{l}\text { İletişimsel Bir Ortam Olarak Sosyal Medya Ve } \\
\text { Demokrasi }\end{array}$ & $\begin{array}{l}\text { Mustafa Ali } \\
\text { Minarl1 }\end{array}$ & $\begin{array}{l}\text { Marmara } \\
\text { Üniversitesi }\end{array}$ \\
\hline 109 & 2019 & $\begin{array}{l}\text { Katılımcı Kültür Olgusu Bağlamında Sosyal Medya Ve } \\
\text { Çevrimiçi Topluluklar: Netnografik Bir Analiz }\end{array}$ & $\begin{array}{l}\text { Şükriye Eren } \\
\text { Çetin }\end{array}$ & $\begin{array}{l}\text { Akdeniz } \\
\text { Üniversitesi }\end{array}$ \\
\hline 110 & 2019 & $\begin{array}{l}\text { Kişisel ve Marka İmaj Yönetiminin Sosyal Medyada } \\
\text { Dönüşümü }\end{array}$ & Hakan Tan & $\begin{array}{l}\text { İstanbul Aydın } \\
\text { Üniversitesi }\end{array}$ \\
\hline 111 & 2019 & $\begin{array}{l}\text { Kurumsal Bir İletişim Aracı Olarak Kullanılan Sosyal } \\
\text { Medya İletişiminin Kurumsal İtibar Ve Marka Güveni } \\
\text { Üzerindeki Etkisi: Türkiye Otomotiv Sektöründe Bir } \\
\text { Alan Araştırması }\end{array}$ & İbrahim Firat & $\begin{array}{l}\text { Kahramanmaraş } \\
\text { Sütçü İmam } \\
\text { Üniversitesi }\end{array}$ \\
\hline 112 & 2019 & $\begin{array}{l}\text { Küreselleşen Yemek Kültürünün Dönüşümmünde Sosyal } \\
\text { Medyanın Rolü: Instagram Gurmeleri }\end{array}$ & $\begin{array}{l}\text { Ayşegül Elif } \\
\text { Çaycı }\end{array}$ & $\begin{array}{l}\text { İstanbul Ticaret } \\
\text { Üniversitesi }\end{array}$ \\
\hline 113 & 2019 & $\begin{array}{l}\text { Lüks Markalarda Sosyal Medya Pazarlamasının Marka } \\
\text { Değeri Ve Satın Alma Niyetine Etkisi, Kişilik } \\
\text { Özelliklerinin Rolü Üzerine Bir Araştırma }\end{array}$ & Işılay Güzel & $\begin{array}{l}\text { Beykent } \\
\text { Üniversitesi }\end{array}$ \\
\hline 114 & 2019 & $\begin{array}{l}\text { Marka Şehir Oluşumunda İnternet Ve Sosyal Medya } \\
\text { Etkisi: Alanya Örneği }\end{array}$ & Yakup Uslu & Selçuk Üniversitesi \\
\hline 115 & 2019 & Öznenin Özgürlüğü Bağlamında Sosyal Medya & Nazlı Çetin & $\begin{array}{l}\text { İstanbul } \\
\text { Üniversitesi }\end{array}$ \\
\hline 116 & 2019 & $\begin{array}{l}\text { Provenance Use in Social Media Software to Develop } \\
\text { Methodologies for Detection of Information Pollution }\end{array}$ & $\begin{array}{l}\text { Mohamed } \\
\text { Jehad Baeth }\end{array}$ & $\begin{array}{l}\text { Y1ldiz Teknik } \\
\text { Üniversitesi } \\
\end{array}$ \\
\hline 117 & 2019 & $\begin{array}{l}\text { Sağlık İletişiminde Dijital İletişim Kanallarının } \\
\text { Kullanımı: Sektör Aktörlerinin Sosyal Medya } \\
\text { Hesaplarının İncelenmesi }\end{array}$ & Tuba Işık & $\begin{array}{l}\text { İstanbul } \\
\text { Üniversitesi }\end{array}$ \\
\hline 118 & 2019 & $\begin{array}{l}\text { Suriyeli Sığınmacıların, Toplumsal Entegrasyon } \\
\text { Sürecinde Sosyal Medya Araçlarını Kullanım } \\
\text { Alışkanlıkları: Şanlıurfa Örneği }\end{array}$ & $\begin{array}{l}\text { Gökhan } \\
\text { Kuzucanl1 }\end{array}$ & Selçuk Üniversitesi \\
\hline 119 & 2019 & $\begin{array}{l}\text { Sosyal Medya Ağ Firmalarının Değerlemesi: Twitter } \\
\text { Uygulaması }\end{array}$ & Gizem Vergili & $\begin{array}{l}\text { Afyon Kocatepe } \\
\text { Üniversitesi }\end{array}$ \\
\hline 120 & 2019 & $\begin{array}{l}\text { Sosyal Medya Kişilik Özelliklerini Yansıtır Mı? İnsan } \\
\text { Kaynakları Perspektifinde Twitter Üzerinden Bir Söylem } \\
\text { Analizi }\end{array}$ & Ahmet Günay & $\begin{array}{l}\text { Süleyman Demirel } \\
\text { Üniversitesi }\end{array}$ \\
\hline 121 & 2019 & $\begin{array}{l}\text { Sosyal Medya Kullanımı İle Sağlıklı Yaşam Biçimi } \\
\text { Davranışları Ve Risk Faktörleri İlişkisi }\end{array}$ & Dilek Güleç & Gazi Üniversitesi \\
\hline 122 & 2019 & $\begin{array}{l}\text { Sosyal Medya Kullanımının Çalışanlar Açısından } \\
\text { Sonuçları: Bir Alan Araştırması }\end{array}$ & $\begin{array}{l}\text { Sümeyra } \\
\text { Ceyhan }\end{array}$ & $\begin{array}{l}\text { Kahramanmaraş } \\
\text { Sütçü İmam } \\
\text { Üniversitesi }\end{array}$ \\
\hline 123 & 2019 & $\begin{array}{l}\text { Sosyal Medya Pazarlama Uygulamalarına İlişkin Algının } \\
\text { Tüketicilerin Marka Bağlılığı Ve Satın Alma Niyetlerine } \\
\text { Etkisi }\end{array}$ & Ayben Ceyhan & $\begin{array}{l}\text { Beykent } \\
\text { Üniversitesi }\end{array}$ \\
\hline 124 & 2019 & $\begin{array}{l}\text { Sosyal Medya Reklamlarına İlişkin Algıların Reklam } \\
\text { Değerine Ve Marka Farkındalığına Etkisi: Y Kuşağı } \\
\text { Instagram Kullanıcıları Üzerine Bir Araştırma }\end{array}$ & $\begin{array}{l}\text { İbrahim Halil } \\
\text { Efendioğlu }\end{array}$ & $\begin{array}{l}\text { Hasan Kalyoncu } \\
\text { Üniversitesi }\end{array}$ \\
\hline 125 & 2019 & $\begin{array}{l}\text { Sosyal Medya Ve Sosyalleşme: Lisans Öğrencileri } \\
\text { Üzerine Bir Araştırma-Afyon Kocatepe Üniversitesi } \\
\text { Örneği }\end{array}$ & Selçuk Şimşek & Selçuk Üniversitesi \\
\hline 126 & 2019 & $\begin{array}{l}\text { Sosyal Medyada Gelişmeleri Kaçırma Korkusunun } \\
\text { Kişinin Tatil Satın Alma Niyetine Etkisi }\end{array}$ & $\begin{array}{l}\text { Filiz Özlem } \\
\text { Çetinkaya }\end{array}$ & Gazi Üniversitesi \\
\hline
\end{tabular}




\begin{tabular}{cclll}
\hline \multirow{2}{*}{27} & 2019 & $\begin{array}{l}\text { Sosyal Medyada Gerilla Pazarlama Paylaşımlarının } \\
\text { Tüketici Satın Alma Kararına Etkisi }\end{array}$ & $\begin{array}{l}\text { Mehmet } \\
\text { Gökerik }\end{array}$ & $\begin{array}{l}\text { Karabük } \\
\text { Üniversitesi }\end{array}$ \\
\hline 128 & 2019 & $\begin{array}{l}\text { Sosyal Medyada Kanaat Önderi Olarak Ceo’nun } \\
\text { Parasosyal Etkisi: Twıtter Üzerine Bir Çalışma }\end{array}$ & $\begin{array}{l}\text { Aslı Duran } \\
\text { Özcan }\end{array}$ & $\begin{array}{l}\text { İstanbul } \\
\text { Üniversitesi }\end{array}$ \\
\hline 129 & 2019 & $\begin{array}{l}\text { Sosyal Medyadaki Mahremiyet Algısının Belirlenmesi: } \\
\text { X, Y } \\
\text { Ve Z Kuşakları Üzerinde Bir Araştırma }\end{array}$ & Elif Kütükoğlu & Erciyes Üniversitesi \\
\hline 130 & 2019 & $\begin{array}{l}\text { Sosyal Medyada Kriz Yönetimi: Kurumsal Markalara } \\
\text { İlişkin Değerlendirme }\end{array}$ & Sinan Akseki & Selçuk Üniversitesi \\
\hline 131 & 2019 & $\begin{array}{l}\text { Sosyal Medya Reklamlarında Ünlü Sporcu Kullanımının } \\
\text { Tüketicilerin Satın Alma Davranışlarına Etkisi: X,Y Ve Z } \\
\text { Kuşağ1 Üzerine Niğde İlinde Bir Araştırma }\end{array}$ & $\begin{array}{l}\text { Mehmet } \\
\text { Mürütsoy }\end{array}$ & $\begin{array}{l}\text { Niğde Ömer } \\
\text { Halisdemir } \\
\text { Üniversitesi }\end{array}$ \\
\hline 132 & 2019 & $\begin{array}{l}\text { Sosyal Medya Bağımlılı̆̆ı: Erzurum İli Üzerine Bir } \\
\text { Inceleme }\end{array}$ & $\begin{array}{l}\text { Özlem Deniz } \\
\text { Duman }\end{array}$ & Atatürk Üniversitesi \\
\hline 133 & 2019 & $\begin{array}{l}\text { Sosyal Medya Fenomenlerinin Tüketici Algısı Ve Satın } \\
\text { Alma Niyeti Üzerine Etkisi }\end{array}$ & $\begin{array}{l}\text { Muhammed } \\
\text { Fatih Cevher }\end{array}$ & $\begin{array}{l}\text { Beykent } \\
\text { Üniversitesi }\end{array}$ \\
\hline 134 & 2019 & $\begin{array}{l}\text { Şehir Markalaşmasında Sosyal Medya Kullanımının } \\
\text { Şehir İmajına Katkısı: İzmir Örneği }\end{array}$ & Mustafa Yalçın & Ege Üniversitesi \\
\hline 135 & 2019 & $\begin{array}{l}\text { Türkiye'de Değişen Dindarlık Göstergeleri Ve Sosyal } \\
\text { Medya }\end{array}$ & $\begin{array}{l}\text { Filiz Çömez } \\
\text { Polat }\end{array}$ & $\begin{array}{l}\text { İstanbul } \\
\text { Üniversitesi }\end{array}$ \\
\hline
\end{tabular}

\section{ETİK ve BİLIMSEL İLKELER SORUMLULUK BEYANI}

$\mathrm{Bu}$ çalışmanın tüm hazırlanma süreçlerinde etik kurallara ve bilimsel atıf gösterme ilkelerine riayet edildiğini yazar(lar) beyan eder. Aksi bir durumun tespiti halinde Afyon Kocatepe Üniversitesi Sosyal Bilimler Dergisi'nin hiçbir sorumluluğu olmayıp, tüm sorumluluk makale yazarlarına aittir.

\section{ARAȘTIRMACILARIN MAKALEYE KATKI ORANI BEYANI}

1. yazar katkı oranı : \% 100 